
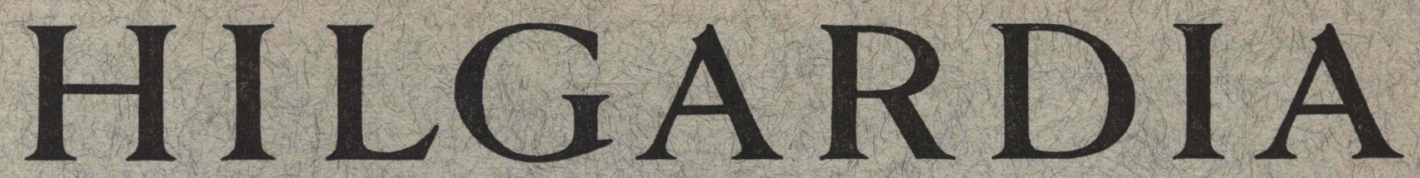

A Journal of Agricultural Science Publisbed by the California Agricultural Experiment Station

\title{
LITTER AND FOREST FLOOR OF THE CHAPARRAL IN PARTS OF THE SAN DIMAS EXPERIMENTAL FOREST, CALIFORNIA
}

\author{
JOSEPH KITTREDGE
}




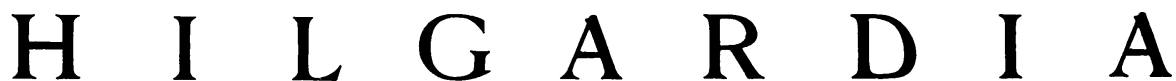

A Journal of Agricultural Science Published by

the California Agricultural Experiment Station

VOL. 23

May, 1955

No. 13

\section{LITTER AND FOREST FLOOR OF THE CHAPARRAL IN PARTS OF THE SAN DIMAS EXPERIMENTAL FOREST, CALIFORNIA}

\section{JOSEPH KITTREDGE}

\section{INTRODUCTION}

Time chaparral is the shrubby, mostly evergreen vegetation on the mountains of southern California. This type of vegetation is influential in securing favorable conditions of water flows-an important factor in the justification of national forests in that part of the state. One of the ways in which the chaparral exerts its influence is through the deposition and accumulation of leaf litter and other organic material on the surface of the ground. The term "litter" will be used herein to denote the annual accumulation, and the term "forest floor," the total organic matter above the surface of the mineral soil at any time, including fresh litter and decomposed older materials. The purpose of this study was to obtain quantitative data on the annual rates of accumulation and decomposition of different types, ages, and densities of chaparral, and the amounts, volume weights, and field moisture capacities of forest floor. Such data constitute a small part of the information needed as a basis for improving the effectiveness of the chaparral as a watershed cover by something corresponding to silvicultural treatment. The rest of the information is being obtained by the members of the California Forest and Range Experiment Station assigned to the Experimental Forest $(13)^{3}$.

\section{PREVIOUS WORK}

The results of records made during the first three years of this project were reported in $1939(7,8)$. Recently detected errors in computations in those reports have been corrected wherever the figures are used in this paper. Data from that period needed for comparisons or the establishment of trends will be reproduced at appropriate points. A review of the literature through 1947 has been made previously (9). At North Fork, California, the annual accumulation for four years was unusually high. On a 1/200acre plot of wedgeleaf ceanothus (Ceanothus cuneatus) and Mariposa man-

${ }^{1}$ Received for publication July 28, 1954.

${ }^{2}$ Professor of Forestry and Forest Ecologist in the Experiment Station, Emeritus, Berkeley.

${ }^{3}$ Italicized figures in parentheses indicate references to "Literature Cited," page 595. 
zanita (Arctostaphylos mariposa) 25 years old and with 0.5 crown coverage, it averaged 2.3 metric tons per acre, with a range in individual years from 2.0 to 3.1. ${ }^{4}$ One to three thousand feet higher, in the Sierra National Forest, under California black oak (Quercus Kelloggii) 75 years old, the average annual accumulation was 0.5 , and the total forest floor 5.6 metric tons per acre (6). In San Benito County, in stands of chamise (Adenostema fasciculatum) of different ages, the total floor, determined as loss on ignition, was 0.85 metric tons per acre at 10 years; 1.9 at 25 years; 2.5 at 50 years; and 2.3 at 90 years (3). In comparison with the foregoing amounts, the annual accumulations in well-stocked stands in the Pacific Northwest are surprisingly low (14). Western red cedar was the highest, with 0.87 metric tons per acre. Bigleaf maple gave 0.60 , red alder, 0.53 , ponderosa pine, 0.33 and 0.25 , and lodgepole pine, 0.12 metric tons per acre. For the woodland chaparral of California buckeye, ceanothus, and other species at North Fork, the $A_{o}$ horizon, $1 / 8$ inch thick, had volume weight of 0.1 , field moisture capacity of 151 per cent, and retention storage of 0.02 inch (10). In experimental pastures in the ponderosa pine-bunch grass type on granite and schist in Colorado, it was concluded that 9 metric tons per acre of litter were needed to provide satisfactory watershed conditions (16). For Monterey pine forest floor in lysimeters, at Berkeley, California, erosion decreased with increases in depth of floor up to $1 / 2$ inch. Floors $1 / 2$ inch or deeper completely controlled erosion (11).

\section{Location and Methods}

The samples were collected from the headwaters of Bell Canyon, at elevations between 2,500 and 3,500 feet, and of Fern Canyon, at elevations between 4,500 and 5,400 feet. Both locations are in the San Dimas Experimental Forest, a part of the Angeles National Forest. Slopes varied from 10 to 50 degrees. The gravelly sandy loam soils were subject to creep of the loose surface materials. Annual accumulations were collected from 1935 to 1953 in 3-by-3-foot trays with fine screen-wire bottoms. The trays were placed on the sloping surfaces and located alternately 33 feet above and below the rain gages along the contour trails which were at 250 - or 300 -foot vertical intervals. The square-foot samples of forest floor were taken in 1950, 6 feet above or below the trays. The rain gages and thus, also, the litter and floor samples were located systematically to give representation of the different facets of slope (17) and, incidentally, of the different types of chaparral. Thus, numbers of samples for different types in the tables are roughly proportional to the areas occupied.

In Bell Canyon, 14 types were distinguished initially, based on the one or two species predominating in crown coverage in each type. For this same area of Bell Canyon, Horton's analysis (5), based on field work in 1934 and 1935, recognized four associations. (1) The chamise-chaparral, dominated by chamise, hoaryleaf ceanothus (Ceanothus crassifolius), and black sage (Salvia mellifera), occupied two thirds of the area, with average crown coverage of 48 per cent. (2) Chamise-sage, characterized by California buck-

\footnotetext{
+ Unpublished data furnished through the courtesy of P. B. Rowe of the California Forest and Range Experiment Station, U. S. Forest Service.
} 
wheat (Eriogonum fasciculatum var. foliolosum), chamise, and black sage, had crown coverage of 24 per cent. (3) Oak-chaparral formed a dense growth of California scrub oak (Quercus dumosa), hoaryleaf ceanothus, and hairy ceanothus (Ceanothus oliganthus). (4) Mixed chaparral was dominated by hoaryleaf ceanothus, Christmasberry (Photinia arbutifolia), Eastwood manzanita (Arctostaphylos glandulosa Eastw.), and other species. The chaparral in Bell Canyon started after a fire in 1919, thus it was 14 years old in 1933 and 34 years old in 1953.

In Fern Canyon, nine types were recognized before differences proved to be not significant. In 1933, the chaparral was more than 55 years old. In the late fall of 1938, a fire completely destroyed both the chaparral and the forest floor, so that the new growth was only 14 years old in 1953. During the first four years after the fire, the same species sprouted or grew from seed, together with many herbaceous plants. The most noticeable change was the appearance of stands of deer brush (Ceanothus integerrimus) over large areas where it had not been present before the fire, except as an occasional dead shrub under the oaks.

Crown coverage and heights, by species, were estimated for the milacre quadrat at each sampling point. Coverage of forest floor was estimated both for the square-foot samples and for the milacre quadrats. Depth of floor was measured and organic matter collected without including mineral soil. In the laboratory, both litter and floor samples were sieved and panned to separate mineral particles from the organic matter. Oven-dry weights were determined and converted to metric tons per horizontal acre. Volume weights, in grams dry weight per gram of water of equal volume, were also computed. For some of the 1950 floor samples, these determinations were made both before and after separation of mineral matter. Field moisture capacities were determined by a modification of Shaw's method (12), and were expressed as per cent of oven-dry weight and in inches depth of water. ${ }^{5}$ Each sample was placed in a cylinder 4 inches in diameter and 18 inches long. Cheesecloth covered the lower end, and a perforated plate covered the top. The cylinder was immersed in water for 72 hours. It was then removed from the water and allowed to drain freely for half a minute. The end covered with cheesecloth was inserted to a depth of 2 inches in a box of dry silt loam soil and left to drain for 48 hours. The top of the cylinder was covered with waxed cloth to prevent evaporation. The weight at the end of 48 hours, less the oven-dry weight, was considered to represent field capacity.

\section{RESULTS}

Crown and Floor Coverage.-The average crown coverage for all types in Bell Canyon increased from 0.7 to 0.8 as the chaparral grew from 14 to 31 years after the fire of 1919. In Fern Canyon, 11 growing seasons after the fire of 1938 , it was 0.8 , the same as in the 50-year-old cover before the fire. All of the important individual types increased in density. This is shown in table 1 where the types are arranged in descending order of the coverage in

\footnotetext{
¿ The work was made possible by the allotment of funds from a special State appropriation for research in forestry in coöperation with Federal agencies.
} 
1950. In Fern Canyon, only the Eastwood manzanita (Agl), the chaparral whitethorn (Ceanothus leucodermis)-manzanita mixture (Cl-Agl), and the mixed oak type (Qc-Qw) increased in coverage. In Bell Canyon, the types with hoaryleaf ceanothus (Ccr) as a component had greater densities than did those without it. In Fern Canyon since the fire, the pure types of in-

TABLE 1

AVERAGE CROWN COVERAGE AND FLOOR COVERAGE BY CHAPARRAI TYPES, 1950 AND 1933

\begin{tabular}{|c|c|c|c|c|c|c|c|c|c|}
\hline \multicolumn{5}{|c|}{ Bell Canyon } & \multicolumn{5}{|c|}{ Fern Canyon } \\
\hline \multirow{2}{*}{$\underset{\text { type* }}{\text { Chaparral }}$} & \multicolumn{2}{|c|}{ Crown coverage } & \multicolumn{2}{|c|}{ Floor coverage } & \multirow{2}{*}{$\underset{\text { type* }}{\text { Chaparral }}$} & \multicolumn{2}{|c|}{ Crown coverage } & \multicolumn{2}{|c|}{ Floor coverage } \\
\hline & 1950 & 1933 & 1950 & 1933 & & 1950 & 1933 & 1950 & 1933 \\
\hline Qw.. & 1.0 & 1.0 & 0.7 & 0.9 & Qc-Qw . . & 1.1 & 0.9 & 0.9 & 0.9 \\
\hline $\mathrm{Pa} . . . \ldots$ & 1.0 & 0.8 & 0.9 & 0.8 & Cl-Agl. . & 1.0 & 0.8 & 0.3 & 1.0 \\
\hline Ro-Af.... & 1.0 & 0.8 & 0.9 & 0.9 & Agl..... & 0.9 & 0.8 & 0.9 & 0.9 \\
\hline Ccr-Af.... & 0.9 & 0.7 & 0.8 & 0.7 & Ci....... & 0.9 & $\ldots$ & 0.8 & $\ldots$ \\
\hline Sm-Ccr. . & 0.9 & 0.7 & 0.8 & 0.7 & Qc-Ci ........ & 0.9 & $\ldots$ & 0.9 & $\ldots$ \\
\hline Ccr-Sm . & 0.9 & 0.7 & 0.7 & 0.7 & Af $-\mathrm{Cl} \ldots \ldots$ & 0.8 & 0.9 & 0.5 & 0.4 \\
\hline Gv....... & 0.8 & 0.6 & 0.9 & 0.9 & Qw........ & 0.8 & 0.9 & 0.8 & 0.9 \\
\hline Agl-Ccr. . . . & 0.8 & $\ldots$ & 0.8 & $\ldots$ & Qc.......... & 0.7 & 0.9 & 0.7 & 0.9 \\
\hline Af-Ccr..... & 0.8 & 0.7 & 0.7 & 0.7 & Agl-Cl $\ldots \ldots$ & 0.6 & 0.9 & 0.8 & 0.9 \\
\hline Qd...... & 0.8 & 0.7 & 0.9 & 0.8 & Cl......... & 0.6 & 0.6 & 0.7 & 0.6 \\
\hline Agl .... & 0.8 & 0.7 & 0.6 & 0.7 & & - & - & - & - \\
\hline Af-Sm. & 0.7 & 0.6 & 0.7 & 0.7 & Mean.... & 0.83 & 0.85 & 0.74 & 0.87 \\
\hline Sm-Af & 0.7 & 0.5 & 0.7 & 0.6 & & & & & \\
\hline Eff....... & 0.3 & 0.4 & 0.6 & 0.6 & & & & & \\
\hline Mean.. & 0.81 & 0.67 & 0.74 & 0.72 & & & & & \\
\hline
\end{tabular}

* Af, Adenostema fasciculatum, chamise

Agl, Arctostaphylos glandulosa Eastw., Eastwood manzanita

Ccr, Ceanothus crassifolius, hoaryleaf ceanothus

$\mathrm{Ci}, \mathrm{C}$. integerrimus, deer brush

Cl, C. leucodermis, chaparral whitethorn

Eff, Eriogonum fasciculatum var. foliolosum, California buckwheat

Gv, Garrya veatchii, silktassel

$\mathrm{Pa}$, Photinia arbutifolia, Christmasberry

Qc, Quercus chrysolepis, canyon live oak

Qd, Q. dumosa, scrub oak

Qw, $Q$. wislizenii, interior live oak

Ro, Rhus ovata, sugarbush

Sm, Salvia mellifera, black sage

terior live oak (Quercus wislizenii) and canyon live oak (Q. chrysolepis), and those with chaparral whitethorn $(\mathrm{Cl})$ in mixture were generally less dense than the others.

The changes in coverage, from 1935 to 1950 , on many quadrats involved also changes in species or proportions of species in the mixed types. Thus black sage $(\mathrm{Sm})$ increased on 85 per cent of the quadrats, chamise (Af) decreased on 60 per cent, and hoaryleaf ceanothus (Cer) decreased on 77 per cent. In Fern Canyon, where the effect of the fire of 1938 was a factor, deer brush $(\mathrm{Ci})$ increased on 89 per cent of the quadrats, interior live oak $(\mathrm{Qw})$ on 80 per cent, and chaparral whitethorn $(\mathrm{Cl})$ on 77 per cent. Canyon live oak (Qc) decreased on 60 per cent, and Eastwood manzanita (Agl) on 57 per cent of the quadrats. These percentages were derived from the quadrats on which the species were represented in all cases. 


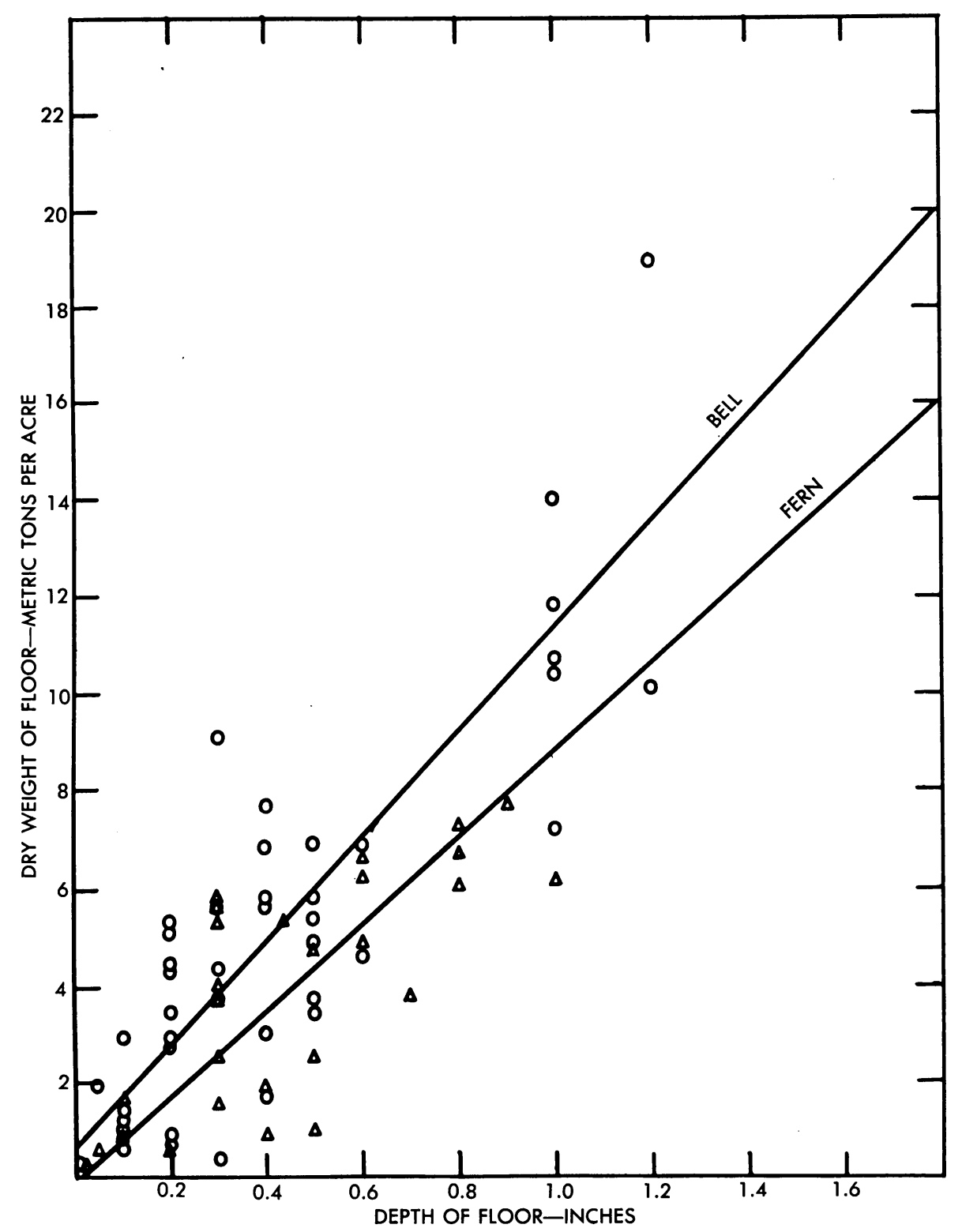

Fig. 1.-Relation of dry weight $(W)$ to depth $(D)$ of forest floor. In Bell Canyon, $W=10.8 D+0.6$; in Fern Canyon, $W=8.8 D-0.1$.

The coverage of forest floor in Bell Canyon for the area as a whole remained at 0.7. In Fern Canyon, the 0.87 of forest floor before the fire had recovered only to 0.74 in the 11 years after the fire. The decreases were in the pure oak types and in the mixed types of chaparral whitethorn $(\mathrm{Cl})$ and Eastwood manzanita ( $\mathrm{Agl})$. In Bell Canyon there were increases in the 
two types in which black sage $(\mathrm{Sm})$ was dominant and in the ceanothuschamise (Ccr-Af) and scrub oak (Quercus dumosa) types.

The relation between crown and floor coverage is subject to wide variation in individual quadrats and between different chaparral types. Averages for large areas and in different years, however, differ by less than 0.1 coverage. There are poorly defined trends from which approximate expressions of the relation can be derived. For both Bell and Fern canyons in 1950, $F=0.85 C^{\frac{1}{2}}$ where $F$ is coverage of floor and $C$ is coverage of crowns, both in tenths of a possible complete coverage as 1.0. For Fern Canyon in 1933, when the area had not been burned for more than 50 years, the relation was, $F=0.9 C^{2}$. These equations indicate equality of floor and crown coverage at 0.74 and 0.85 , respectively.

Depth and Dry Weight of Forest Floor.-The average depth of the floor in Bell Canyon increased from 0.2 to 0.4 inch in the 17 years from 1933 to 1950. None of the widely distributed types within the Canyon area increased more than 0.2 inch, and none decreased. The mean depths of floor, by types, are shown in tables 2 and 3. In Fern Canyon, the comparison is between the 50 -year stands of 1933 and the 11-year stands of 1950. The average depth of floor in 1933 was 0.6 inch and in 1950, only 0.4 inch. Eleven years after the fire of 1938, none of the types had so deep a floor as before the fire, and the difference between individual types was usually 0.2 inch, as it was between the weighted averages for all types. Depth of floor $(D)$ in inches is, of course, a factor in the dry weight $(W)$ in metric tons per acre, and the two are correlated as shown in figure 1. For Bell Canyon, $W=10.8 D+0.6$, and for Fern Canyon, $W=8.8 D-0.1$. Both coefficients are highly significant. The difference between the regression coefficients is not quite significant at the 5 per cent level, although the two trends are both shown in figure 1 . When the data are combined, the regression becomes $W=9.7 D+0.4$. Thus dry weight per acre could be estimated approximately from the depth. The relations between dry weight and coverage of either crowns or floor were not sufficiently well defined to be useful.

The dry weights used in this paper are those determined after mineral matter had been separated in the laboratory. The amount of mineral matter contained in the field samples was quite large even when care was taken, in collecting, not to include it. This is shown by determinations of dry weights, which averaged 8.7 metric tons per acre before separation, and 4.6 after separation. The relation of dry weight after separation $\left(W_{a}\right)$ to that before $\left(W_{b}\right)$ can be expressed as $W_{a}=0.44 W_{b}+0.7$ for all the data, and the corresponding trend for Bell Canyon is shown in figure 2. Both regression coefficients are highly significant. In fact, dry weights after separation of mineral matter might be estimated fairly accurately from weights before separation by the use of this relation. Thus the time-consuming separation in the laboratory could be avoided. Use of the formula should be based on the assumption that, in collecting samples, as much care would be taken to exclude mineral matter as was taken in this study. The average loss on ignition of samples from Bell Canyon was 73.2 per cent, and from Fern Canyon, 74.8 per cent after separation of the mineral matter-figures that suggest that even after separation, some mineral particles adhered to the organic matter. 
Dry weights, depths, and other properties were first segregated by the types of chaparral as characterized by the one or two predominant species. The means of dry weight for the different chaparral types and groups are arranged in descending sequence in tables 2 and 3 . The types and groups are reproduced in reverse order, as column headings, to form a cross-classification in which the intersection of any line and column shows the significance or nonsignificance of the difference between means of any two types at the 5 per cent level of probability. Types represented by only one sample have no entries because they do not provide a basis for a test of significance.

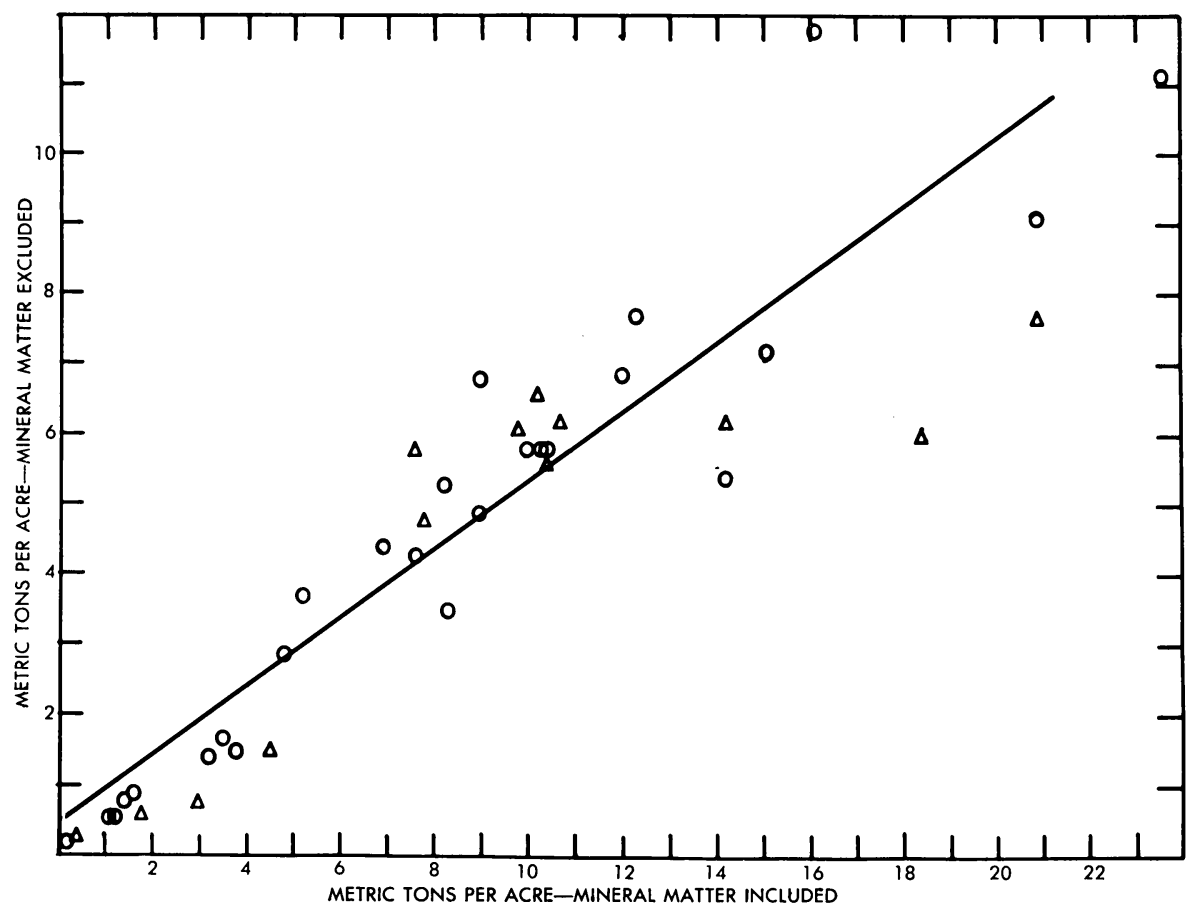

Fig. 2.-Relation of dry weight of forest floor excluding mineral matter $(Y)$ to dry weight including mineral matter $(X)$ for Bell Canyon, $Y=0.5 X+0.5$.

The differences between types were significant only between the extremes, as indicated in tables 2 and 3. For that reason, the types were combined in groups, which, while more diverse in composition, differed significantly in their properties. For depth and dry weight, three groups were distinguished in Bell Canyon and two in Fern Canyon. In Bell Canyon, the means of dry weight of the groups of table 2 showed significant differences. Thirtyone years after the fire, the group characterized by California scrub oak (Qd), silktassel (Garrya veatchii), and sugarbush (Rhus ovata) had an average of 15.2 metric tons per acre dry weight and, at the low end, the group in which chamise (Af), interior live oak (Qw), Eastwood manzanita $(\mathrm{Agl})$, or California buckwheat (Eff) predominated, had only 2.6 metric tons. Between 2,500 and 3,500 feet, in these mountains, the first group is 
TABLE 2

DRY WEIGHT AND DEPTH OF FOREST FLOOR IN 31-YEAR-OLD CHAPARRAL OF BELL CANYON

\begin{tabular}{|c|c|c|c|c|c|c|c|c|c|c|}
\hline \multirow{2}{*}{$\begin{array}{c}\text { Group and } \\
\text { chaparral } \\
\text { type }\end{array}$} & \multirow{2}{*}{$\begin{array}{l}\text { Num- } \\
\text { ber of } \\
\text { samples }\end{array}$} & \multirow{2}{*}{$\begin{array}{c}\text { Means of } \\
\text { dry } \\
\text { weight } \\
\text { per acre }\end{array}$} & \multicolumn{7}{|c|}{ Significance of differences between means of dry weight $\dagger$} & \multirow{2}{*}{$\begin{array}{c}\text { Means of } \\
\text { depth }\end{array}$} \\
\hline & & & Af-Sm & Af-Ccr & Ccr-Sm & Sm-Cer & Sm-Af & Ccr-Af & Agl-Ccr & \\
\hline & & $\begin{array}{l}\text { metric } \\
\text { tons }\end{array}$ & & & & & & & & inches \\
\hline \multicolumn{11}{|l|}{ High group: } \\
\hline $\mathrm{Qd} \ldots \ldots \ldots$ & 3 & 17.7 & $\mathbf{s}$ & $\mathbf{s}$ & $\mathbf{s}$ & $\mathbf{s}$ & $\mathbf{s}$ & $\mathbf{s}$ & $\mathbf{n}$ & 1.4 \\
\hline Gv......... & 1 & 14.1 & . &.. & .. & . & .. & .. & .. & 1.0 \\
\hline Ro-Af $\ldots \ldots$ & 1 & 9.1 & .. & .. & .. & .. & .. & .. & . & 0.3 \\
\hline \multicolumn{11}{|l|}{ Medium group: } \\
\hline Agl-Cer...... & 2 & 5.5 & $\mathbf{s}$ & $\mathbf{n}$ & $\mathbf{n}$ & $\mathbf{n}$ & $\mathbf{n}$ & $\mathbf{n}$ & $\cdots$ & 0.6 \\
\hline Ccr-Af........ & 7 & 5.1 & $\mathbf{n}$ & $\mathrm{n}$ & $\mathbf{n}$ & $\mathbf{n}$ & $\mathbf{n}$ & .. & .. & 0.4 \\
\hline Sm-Af....... & 9 & 4.8 & $\mathbf{n}$ & $\mathbf{n}$ & $\mathbf{n}$ & $\mathbf{n}$ & .. & . & . & 0.4 \\
\hline Sm-Ccr...... & 4 & 4.5 & s & $\mathbf{n}$ & $\mathbf{n}$ & .. & .. & . & . & 0.4 \\
\hline $\mathrm{Pa} \ldots \ldots \ldots \ldots$ & 1 & 4.3 & .. & .. & .. & .. & .. & .. & . & 0.2 \\
\hline Ccr-Sm...... & 6 & 4.1 & $\mathbf{n}$ & $\mathbf{n}$ & .. & . & .. & . & . & 0.3 \\
\hline \multicolumn{11}{|l|}{ Low group: } \\
\hline Af-Ccr......... & 7 & 3.0 & . & .. & . & .. & .. & .. & . & 0.2 \\
\hline Qw.......... & 1 & 2.9 & .. & .. & .. & . & .. & .. & .. & 0.3 \\
\hline Agl........... & 1 & 2.7 & .. & .. & $\ddots$. & .. & .. & .. & . & 0.2 \\
\hline Af-Sm........ & 4 & 2.3 & . & .. & .. & .. & .. & $\ldots$ & $\ldots$ & 0.1 \\
\hline Eff $\ldots \ldots \ldots$ & 1 & 0.7 & .. & .. & .. & .. & .. & .. & . & 0.2 \\
\hline
\end{tabular}

Group means

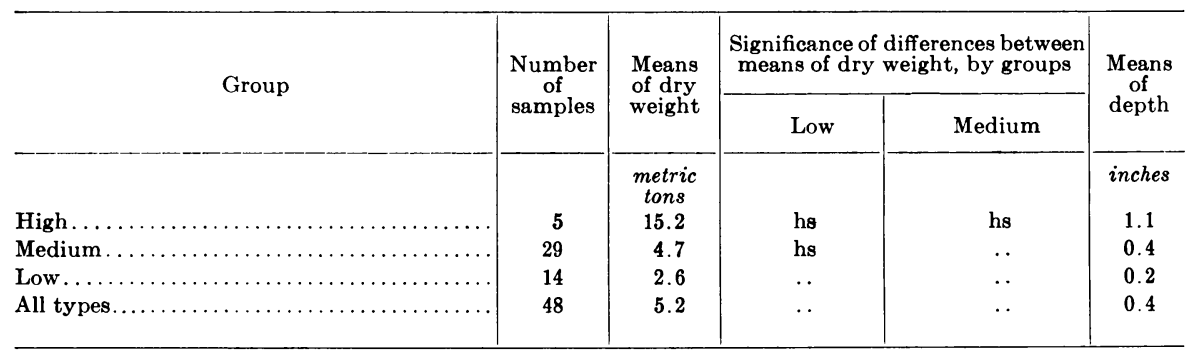

* Af, Adenostema fasciculatum, chamise

Agl, Arctostaphylos glandulosa Eastw., Eastwood manzanita

Ccr, Ceanothus crassifolius, hoaryleaf ceanothus

Eff, Eriogonum fasciculatum var. foliolosum, California buckwheat

$\mathrm{Gv}$, Garrya veatchii, silktassel

$\mathrm{Pa}$, Photinia arbutifolia, Christmasberry

Qd, Quercus dumosa, scrub oak

Qw, Q. wislizenii, interior live oak

Ro, Rhus ovata, sugarbush

Sm, Salvia mellifera, black sage

$\dagger \mathrm{s}=$ significant; $\mathrm{hs}=$ highly significant; $\mathrm{n}=$ not significant.

evidently more effective than are the other two in providing a litter cover for the soil.

In Fern Canyon 11 years after the fire, the high group characterized by Eastwood manzanita $(\mathrm{Agl})$ and deer brush $(\mathrm{Ci})$, with 5.2 metric tons per acre, exceeded the 3.1 tons of the combined medium and low groups containing the live oaks, whitethorn, and chamise. The combination was made because the mean of the medium group was not significantly different from that of the high or of the low group. With the exception of the 15.2 tons per acre of the high group in Bell Canyon, the differences between canyons 
are small, and may reflect the differences in age as well as in composition of the chaparral at the different elevations. However, after some years, age may become a negligible factor as indicated by the comparison of the average of all types in Bell Canyon when the chaparral was 31 years old (5.2

TABLE: 3

DRY WEIGHT AND DEPTH OF FOREST FLOOR IN 11-YEAR-OLD CHAPARRAL OF FERN CANYON

\begin{tabular}{|c|c|c|c|c|c|c|c|c|c|c|}
\hline \multirow{2}{*}{$\underset{\text { chaparral }}{\text { Group and }}$} & \multirow{2}{*}{$\begin{array}{c}\text { Num- } \\
\text { ber of } \\
\text { samples }\end{array}$} & \multirow{2}{*}{$\begin{array}{l}\text { Means } \\
\text { of dry } \\
\text { weight } \\
\text { per acre }\end{array}$} & \multicolumn{7}{|c|}{ Significance of differences between means of dry weight $\dagger$} & \multirow{2}{*}{$\begin{array}{l}\text { Means } \\
\text { of depth }\end{array}$} \\
\hline & & & $\mathrm{Cl}$ & Agl-Cl & $\mathrm{Af}-\mathrm{Cl}$ & $\mathrm{Qc}-\mathrm{Ci}$ & Qw & Qc & $\mathrm{Ci}$ & \\
\hline & & $\begin{array}{c}\text { metric } \\
\text { tons }\end{array}$ & & & & & & & & inches \\
\hline \multicolumn{11}{|l|}{ High group: } \\
\hline Agl......... & 3 & 5.4 & $\mathbf{s}$ & $\mathbf{n}$ & $\mathbf{n}$ & $\mathbf{n}$ & $\mathbf{n}$ & $\mathbf{n}$ & $\mathbf{n}$ & 0.7 \\
\hline $\mathbf{C i} \ldots \ldots \ldots$ & 7 & 5.1 & $\mathbf{n}$ & $\mathbf{n}$ & $\mathbf{n}$ & $\mathbf{n}$ & $\mathbf{n}$ & $\mathrm{n}$ & . & 0.3 \\
\hline \multicolumn{11}{|l|}{ Medium group: } \\
\hline Qc......... & 9 & 4.1 & $\mathbf{n}$ & $\mathbf{n}$ & $\mathbf{n}$ & $\mathbf{n}$ & $\mathbf{n}$ & . & .. & 0.5 \\
\hline Qw......... & 3 & 3.9 & $\mathbf{n}$ & $\mathrm{n}$ & $\mathbf{n}$ & $\mathbf{n}$ & . & . & .. & 0.5 \\
\hline Qc-Qw $\ldots .$. & 1 & 3.7 & . & . & . & .. & . & . & .. & 0.3 \\
\hline Qc-Ci $\ldots \ldots$ & 3 & 2.5 & $\mathbf{n}$ & $\mathbf{n}$ & $\mathbf{n}$ & .. & . & . & .. & 0.4 \\
\hline \multicolumn{11}{|l|}{ Low group: } \\
\hline $\mathrm{Af}-\mathrm{Cl} \ldots \ldots$ & 2 & 2.3 & $\mathbf{n}$ & $\mathbf{n}$ & $\ldots$ & $\ldots$ & .. & .. & .. & 0.2 \\
\hline Agl-Cl..... & 2 & 2.0 & $\mathrm{~s}$ & .. & .. & .. & . & $\ldots$ & .. & 0.2 \\
\hline $\mathrm{Cl} \ldots \ldots \ldots$ & 2 & 1.1 & .. & .. & .. & .. & .. & $\cdots$ & .. & 0.1 \\
\hline Cl-Agl...... & 1 & 0.2 & .. & .. & . & .. & .. & . & .. & 0.1 \\
\hline
\end{tabular}

Group means

\begin{tabular}{|c|c|c|c|c|c|c|}
\hline \multirow{2}{*}{ Group } & \multirow{2}{*}{$\begin{array}{c}\text { Number } \\
\text { of } \\
\text { samples }\end{array}$} & \multirow{2}{*}{$\begin{array}{l}\text { Means } \\
\text { of dry } \\
\text { weight }\end{array}$} & \multicolumn{3}{|c|}{$\begin{array}{l}\text { Significance of differences between } \\
\text { means of dry weight, by groups }\end{array}$} & \multirow{2}{*}{$\begin{array}{c}\text { Means } \\
\text { of } \\
\text { depth }\end{array}$} \\
\hline & & & $\begin{array}{l}\text { Medium } \\
\text { and low }\end{array}$ & Low & Medium & \\
\hline High. . & 10 & $\begin{array}{l}\text { metric tons } \\
\quad 5.2\end{array}$ & $\mathbf{s}$ & $\mathbf{s}$ & $\mathbf{n}$ & $\begin{array}{c}\text { inches } \\
0.4\end{array}$ \\
\hline Medium. & 16 & 3.7 & $\mathrm{n}$ & $\mathbf{n}$ & . & 0.5 \\
\hline Low...... & 7 & 1.6 & .. & .. & .. & 0.2 \\
\hline Medium and low.... & 23 & 3.1 & . & . & . & 0.4 \\
\hline All types.............. & 33 & 3.7 & . & . & . & 0.4 \\
\hline
\end{tabular}

* Af, Adenostema fasciculatum, chamise

Agl, Arctostaphylos glandulosa Eastw., Eastwood manzanita

Ci, Ceanothus integerrimus, deer brush

Cl, C. leucodermis, chaparral whitethorn

Qc, Quercus chrysolepis, canyon live oak

$\mathrm{Qw}, Q$. wislizenii, interior live oak

$\dagger \mathrm{s}=$ significant; $\mathrm{n}=$ not significant.

tons per acre) with the average in 1933 when it was 14 years old ( 5.3 tons per acre) (8). On the other hand, in Fern Canyon, the average at 50 years of age, before the fire, was 15.1 tons per acre, whereas the 11-year-old stands after the fire had only 3.7 tons per acre.

Volume Weight of Forest Floor.-Volume weight was determined as the ratio of the oven-dry weight of a sample to the weight of a volume of water equal to that of the sample as collected. The volume weights are not closely correlated with dry weights per acre. Consequently, the sequence of chaparral types and the groups characterized by significantly different mean 
volume weights in tables 4 and 5 are not the same as for dry weight. The high group in Bell Canyon, with average volume weight of 0.21 gram per gram, includes the interior live oak $(\mathrm{Qw})$, Christmasberry $(\mathrm{Pa})$ and sugarbush (Ro) types. The low group, with volume weight of 0.08 , includes

TABLE 4

VOLUME WEIGHT OF FOREST FLOOR IN 31-YEAR-OLD CHAPARRAL OF BELL CANYON

\begin{tabular}{|c|c|c|c|c|c|c|c|c|}
\hline \multirow{2}{*}{$\begin{array}{l}\text { Group and } \\
\text { chaparral type* }\end{array}$} & \multirow{2}{*}{$\begin{array}{l}\text { Number } \\
\text { of } \\
\text { samples }\end{array}$} & \multirow{2}{*}{$\begin{array}{l}\text { Means } \\
\text { of } \\
\text { volume } \\
\text { weight }\end{array}$} & \multicolumn{6}{|c|}{ Significance of differences between means } \\
\hline & & & Agl-Ccr & Qd & $\mathrm{Af}-\mathrm{Cc}$ & Sm-Af & Sm-Cer & Cer-Af \\
\hline \multicolumn{7}{|l|}{ High group: } & & \\
\hline $\begin{array}{l}\text { Hign group: } \\
\text { Ro-Af ........... }\end{array}$ & 1 & 0.26 & .. & .. & .. & . & .. & .. \\
\hline Qw............ & 1 & 0.19 & . & .. & $\cdots$ & . & .. & $\cdots$ \\
\hline $\mathrm{Pa} \ldots \ldots \ldots \ldots$ & 1 & 0.17 & . & . & . & . & .. & . \\
\hline \multicolumn{9}{|l|}{ Medium group: } \\
\hline Af-Sm $\ldots \ldots$ & 4 & 0.14 & $\mathbf{n}$ & $\mathbf{n}$ & $\mathbf{n}$ & $\mathbf{n}$ & $\mathbf{n}$ & $\mathbf{n}$ \\
\hline Gv........... & 1 & 0.13 & . & .. & .. & . & . & . \\
\hline Cer-Af..... & 6 & 0.13 & $\mathbf{n}$ & $\mathbf{n}$ & $\mathbf{n}$ & $\mathbf{n}$ & $\mathbf{n}$ & .. \\
\hline Agl $\ldots \ldots \ldots \ldots$ & 1 & 0.12 & . & .. & . & . & . & .. \\
\hline Cer-Sm ........ & 6 & 0.12 & $\mathrm{n}$ & n & $\mathbf{n}$ & $\mathrm{n}$ & $\mathrm{n}$ & .. \\
\hline Sm-Ccr . . . . . . & 4 & 0.12 & $\mathrm{n}$ & $\mathbf{n}$ & n & $\mathbf{n}$ & $\ldots$ & .. \\
\hline Sm-Af ........ & 8 & 0.11 & $\mathrm{n}$ & $\mathrm{n}$ & $\mathrm{n}$ & . & .. & . \\
\hline Af-Ccr............ & 7 & 0.11 & $\mathrm{n}$ & $\mathrm{n}$ & .. & . & $\cdots$ & $\cdots$ \\
\hline \multicolumn{9}{|c|}{ Low group: } \\
\hline Qd........ & 3 & 0.10 & $\mathrm{n}$ & . & .. & . & . & .. \\
\hline Agl-Cer. . & 2 & 0.08 & .. & . & . & . & . & .. \\
\hline Eff.......... & 1 & 0.03 & .. & . & . & . & . & .. \\
\hline \multicolumn{9}{|c|}{ Group means } \\
\hline \multirow{2}{*}{\multicolumn{3}{|c|}{ Group }} & \multirow{2}{*}{$\begin{array}{c}\text { Number } \\
\text { of } \\
\text { samples }\end{array}$} & \multirow{2}{*}{\multicolumn{2}{|c|}{$\begin{array}{c}\text { Means } \\
\text { of volume } \\
\text { weight }\end{array}$}} & \multicolumn{3}{|c|}{$\begin{array}{l}\text { Significance of differences between } \\
\text { means of volume weight, by groups }\end{array}$} \\
\hline & & & & & & Low & & ium \\
\hline \multirow{4}{*}{\multicolumn{3}{|c|}{ 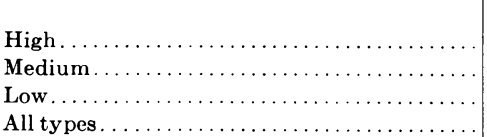 }} & 3 & \multicolumn{2}{|c|}{$\begin{array}{c}g / g \\
0.21\end{array}$} & hs & \multicolumn{2}{|c|}{$\mathbf{s}$} \\
\hline & & & 37 & \multicolumn{2}{|c|}{0.12} & s & \multicolumn{2}{|c|}{. } \\
\hline & & & 6 & \multicolumn{2}{|c|}{0.08} & .. & \multicolumn{2}{|r|}{.. } \\
\hline & & & 46 & \multicolumn{2}{|c|}{0.12} & .. & \multicolumn{2}{|r|}{.. } \\
\hline
\end{tabular}

* Af, Adenostema fasciculatum, chamise

Agl, Arctostaphylos glandulosa Eastw., Eastwood manzanita

Ccr, Ceanothus crassifolius, hoaryleaf ceanothus

Eff, Eriogonum fasciculatum var. foliolosum, California buckwheat

$\mathrm{Gv}$, Garrya veatchii, silktassel

$\mathrm{Pa}$, Photinia arbutifolia, Christmasberry
$\mathrm{Qd}$, Quercus dumosa, scrub oak

Qw, Q. wislizenii, interior live oak

Ro, Rhus ovata, sugarbush

Sm, Salvia mellifera, black sage

the scrub oak (Qd), California buckwheat (Eff), and Eastwood manzanita (Agl) types. Most of the widespread types, including the mixtures of hoaryleaf ceanothus (Ccr), black sage (Sm), and chamise (Af), are in the intermediate group with mean volume weight of 0.12 .

In Fern Canyon, only two groups had significantly different average volume weights. The high group with the deer brush (Ci) and chamise (Af) types had average volume weight of 0.11 , and the combined medium and 
low group with the live oaks, whitethorn $(\mathrm{Cl})$, and Eastwood manzanita $(\mathrm{Agl})$ averaged a volume weight of 0.08 . Comparing the two canyons as units, the average volume weight in Fern Canyon, above 4,700 feet, was 0.09, while that in Bell Canyon, below 3,500 feet, was 0.12. These volume weights are smaller than those determined 17 years earlier (8) but it is not

TABLE 5

VOLUME WEIGHT OF FOREST FLOOR IN 11-YEAR-OLD CHAPARRAL OF FERN CANYON

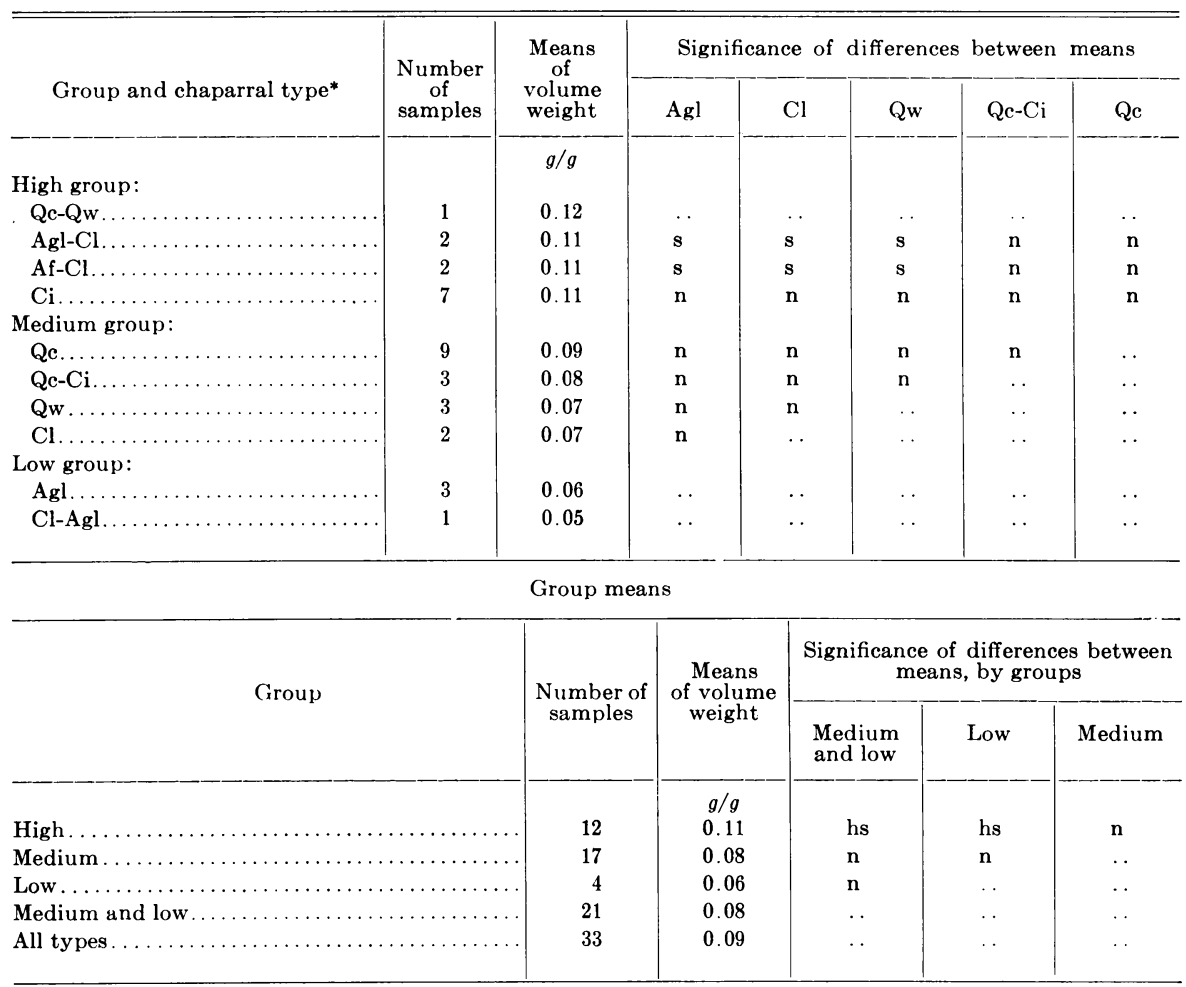

* Af, Adenostema fasciculatum, chamise

Agl, Arctostaphylos glandulosa Eastw., Eastwood manzanita

$\mathrm{Ci}$, Ceanothus integerrimus, deer brush

Cl, C. leucodermis, chaparral whitethorn

Qc, Quercus chrysolepis, canyon live oak

$\mathrm{Qw}, Q$. wislizenii, interior live oak

certain whether the difference may have been caused by less careful measurements of depth of samples at that time or by an actual change, with age, in the density of the forest floor.

The volume weights in tables 4 and 5 are those after separation of mineral matter, and the mean for all data from both canyons was 0.11 . The mean including the mineral matter unintentionally collected was 0.21 , almost twice as large. The two series of values are correlated as shown in figure 3. The relation between them can be expressed as $Y=0.47 X+0.01$, where $Y$ is volume weight excluding mineral matter and $X$ is volume weight including 
it. The regression coefficient is highly significant. It might therefore be possible to use this relation to compute approximate values of volume weight without mineral matter and thus avoid the time and expense of separation. However, it would have to be assumed that samples would be collected with the same care taken to exclude mineral matter.

If it may be assumed that the specific gravity of this organic matter after separation of mineral is about 1.5 , then the pore space for most of the types varies between 91 and 95 per cent by volume.

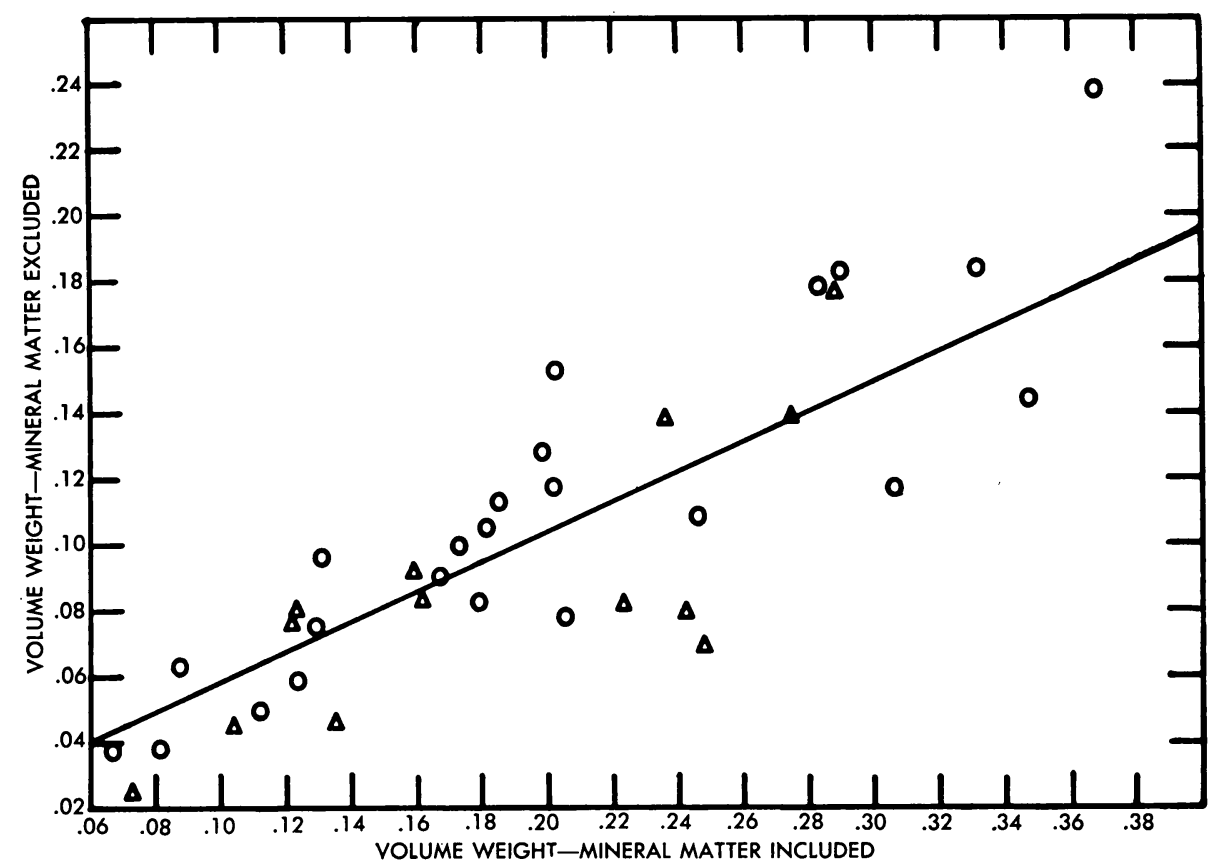

Fig. 3.-Relation of volume weight of forest floor excluding mineral matter $(Y)$ to volume weight including mineral matter $(X)$ for both canyons, $Y=0.47 X+0.01$.

Field Moisture Capacity and Retention Storage.-The sequence of chaparral types and the composition of the groups on the basis of field moisture capacity, as shown in tables 6 and 7, are again somewhat different from those distinguished on other bases. The range for all types and both canyons is only from 115 to 205 per cent of oven-dry weight. The moisture at field capacity or at capillary saturation is that which is retained against the force of gravity. This holding of moisture is called retention storage. Such storage is, however, only temporary, and the moisture is subject to reduction by evaporation, under natural conditions, to the air-dry state at which it is usually between 10 and 15 per cent of oven-dry weight. Thus, the moisture subject to loss by evaporation is less than field capacity by 10 or 15 per cent.

In Bell Canyon, the high group, having the oaks, Christmasberry $(\mathrm{Pa})$, and black sage $(\mathrm{Sm})$ predominant in mixture with hoaryleaf ceanothus, 
TABLE 6

FIELD MOISTURE CAPACITY OF FOREST FLOOR IN 31-YEAR-OLD CHAPARRAL OF BELL CANYON

\begin{tabular}{|c|c|c|c|c|c|c|c|c|c|}
\hline \multirow{2}{*}{$\begin{array}{l}\text { Group and chapar- } \\
\text { ral type* }\end{array}$} & \multirow{2}{*}{$\begin{array}{c}\text { Number } \\
\text { of } \\
\text { samples }\end{array}$} & \multirow{2}{*}{$\begin{array}{l}\text { Field } \\
\text { moisture } \\
\text { capacity }\end{array}$} & \multicolumn{7}{|c|}{ Significance of differences between means } \\
\hline & & & Af-Sm & Af-Ccr & Cer-Af & Agl-Ccr & Sm-Af & Ccr-Sm & Sm-Ccr \\
\hline 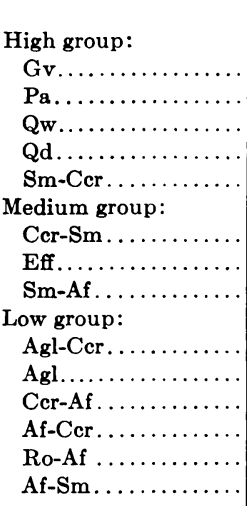 & $\begin{array}{l}2 \\
1 \\
7 \\
7 \\
1 \\
4\end{array}$ & $\begin{array}{c}\text { per cent } \\
205 \\
159 \\
158 \\
157 \\
156 \\
\\
143 \\
143 \\
143 \\
\\
134 \\
134 \\
131 \\
125 \\
125 \\
115\end{array}$ & $\begin{array}{l}\mathbf{s} \\
. . \\
\mathbf{s} \\
\mathbf{n} \\
. . \\
. .\end{array}$ & $\begin{array}{l}. . \\
. \\
. . \\
\mathbf{s} \\
\mathbf{s} \\
\mathbf{s} \\
. . \\
\mathbf{s} \\
\mathbf{n} \\
\ldots \\
\mathbf{n} \\
. . \\
. . \\
. .\end{array}$ & $\begin{array}{l}. . \\
. \\
\ldots \\
\mathbf{s} \\
\mathbf{s} \\
\\
\mathbf{s} \\
. . \\
\mathbf{s} \\
\\
\mathrm{n} \\
\ldots \\
. . \\
. . \\
. . \\
. .\end{array}$ & $\begin{array}{l}. . \\
. . \\
. . \\
\text { s } \\
\text { s } \\
\text { s } \\
. \\
\text { s }\end{array}$ & $\begin{array}{l}. . \\
. . \\
\ldots \\
\text { s } \\
\text { n } \\
\\
\text { n } \\
. . \\
. . \\
\\
. \\
. . \\
. \\
. . \\
. . \\
. .\end{array}$ & $\begin{array}{l}. . \\
. . \\
. . \\
\mathbf{s} \\
\mathbf{s} \\
\\
. . \\
. \\
. . \\
\\
. . \\
. \\
. . \\
. . \\
. \\
. .\end{array}$ & $\begin{array}{l}. . \\
. . \\
. \\
\text { n } \\
. . \\
\\
. . \\
. \\
. . \\
\\
. . \\
. \\
. \\
. . \\
. . \\
. .\end{array}$ \\
\hline \multicolumn{10}{|c|}{ Group means } \\
\hline \multirow{2}{*}{\multicolumn{3}{|c|}{ Group }} & \multirow{2}{*}{\multicolumn{2}{|c|}{$\begin{array}{c}\text { Number } \\
\text { of } \\
\text { samples }\end{array}$}} & \multirow{2}{*}{$\begin{array}{l}\text { Field } \\
\text { moisture } \\
\text { capacity }\end{array}$} & \multicolumn{4}{|c|}{$\begin{array}{c}\text { Significance of differences between } \\
\text { means, by groups }\end{array}$} \\
\hline & & & & & & & Low & $\mathrm{Mec}$ & dium \\
\hline \multicolumn{3}{|c|}{ 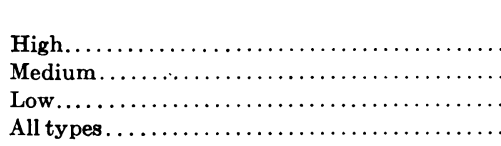 } & \multicolumn{2}{|c|}{$\begin{array}{l}10 \\
16 \\
22 \\
48\end{array}$} & $\begin{array}{c}\text { per cent } \\
161 \\
143 \\
126 \\
139\end{array}$ & & $\begin{array}{l}\text { hs } \\
\text { hs } \\
\ldots \\
\ldots\end{array}$ & $\begin{array}{l}\text { b } \\
\cdot \\
\cdot \\
\text {. }\end{array}$ & . \\
\hline
\end{tabular}

* Af, Adenostema fasciculatum, chamise

Agl, Arctostaphylos glandulosa Eastw., Eastwood manzanita

Ccr, Ceanothus crassifolius, hoaryleaf ceanothus

Eff, Eriogonum fasciculatum var. foliolosum, California buckwheat

$\mathrm{Gv}$, Garrya veatchii, silktassel

$\mathrm{Pa}$, Photinia arbutifolia, Christmasberry

Qd, Quercus dumosa, scrub oak

Qw, Q. wislizenii, interior live oak

Ro, Rhus ovata, sugarbush

Sm, Salvia mellifera, black sage

had field capacity of 161 per cent. The low group, with the chamise (Af) and Eastwood manzanita mixtures, averaged 126 per cent. Both averages differed from the 143 per cent of the medium group with high significance. In fact, the differences between types were frequently significant, as shown in table 6.

In Fern Canyon, the canyon live oak (Qc) and deer brush (Ci) characterized the medium group with average field capacity of 151 per cent. Eastwood manzanita ( $\mathrm{Agl})$, chamise (Af), and whitethorn ( $\mathrm{Cl}$ ) mixtures made up the low group, with mean field capacity of 131 per cent. The pure types of chaparral whitethorn $(\mathrm{Cl})$ and interior live oak $(\mathrm{Qw})$ in the high group 
had an average field capacity of 183 per cent. The differences between groups and between several types in table 7 were significant.

The general average for all types in the 11-year-old chaparral of Fern Canyon at elevations above 4,700 feet was 151 per cent, as compared with 139 per cent in the 31-year-old chaparral of Bell Canyon below 3,500 feet.

TABLE 7

FIELD MOISTURE CAPACITY OF FOREST FLOOR IN 11-YEAR-OLD CHAPARRAL OF FERN CANYON

\begin{tabular}{|c|c|c|c|c|c|c|c|c|c|c|}
\hline \multirow{2}{*}{$\begin{array}{l}\text { Group and } \\
\text { chaparral } \\
\text { type* }\end{array}$} & \multirow{2}{*}{$\begin{array}{l}\text { Num- } \\
\text { ber of } \\
\text { samples }\end{array}$} & \multirow{2}{*}{$\begin{array}{l}\text { Field } \\
\text { moisture } \\
\text { capacity }\end{array}$} & \multicolumn{8}{|c|}{ Significance of differences between means } \\
\hline & & & $\mathrm{Agl}$ & $\mathrm{Cl}-\mathrm{Agl}$ & $\mathrm{Af}-\mathrm{Cl}$ & $\mathrm{Agl}-\mathrm{Cl}$ & Qc-Ci & $\mathrm{Qc}$ & $\mathrm{Ci}$ & $\mathrm{Qw}$ \\
\hline & & per cent & & & & & & & & \\
\hline \multicolumn{11}{|l|}{ High group: } \\
\hline $\mathrm{Cl} . \ldots \ldots \ldots$ & 2 & 187 & $\mathbf{s}$ & $\mathbf{s}$ & $\mathbf{s}$ & s & $\mathbf{s}$ & $\mathbf{s}$ & $\mathbf{s}$ & $\mathrm{n}$ \\
\hline $\mathrm{Qw} \ldots \ldots \ldots$ & 3 & 181 & s & s & s & $\mathrm{n}$ & $\mathbf{s}$ & $\mathbf{s}$ & $\mathbf{s}$ & . \\
\hline \multicolumn{11}{|l|}{ Medium group: } \\
\hline $\mathrm{Ci} \ldots \ldots \ldots$ & 7 & 154 & s & s & $\mathbf{s}$ & $\mathrm{n}$ & $\mathbf{n}$ & $\mathrm{n}$ & .. & . \\
\hline $\mathrm{Qc}-\mathrm{Qw} \ldots \ldots$ & 1 & 152 & . & .. & . & .. & .. & . & .. & . \\
\hline Qc......... & 9 & 152 & $\mathbf{s}$ & s & $\mathrm{n}$ & $\mathrm{n}$ & $\mathbf{n}$ & . & .. & .. \\
\hline Qc-Ci $\ldots \ldots$ & 3 & 146 & $\mathrm{n}$ & $\mathrm{n}$ & $\mathbf{n}$ & $\mathrm{n}$ & . & . & .. & $\ldots$ \\
\hline \multicolumn{11}{|l|}{ Low group: } \\
\hline Agl-Cl $\ldots .$. & 2 & 142 & $\mathbf{s}$ & $\mathbf{n}$ & $\mathbf{n}$ & .. & .. & .. & .. & .. \\
\hline Af-Cl... & 2 & 136 & $\mathbf{n}$ & $\mathbf{n}$ & .. & .. & .. & .. & .. & .. \\
\hline Cl-Agl $\ldots \ldots$ & 1 & 127 & .. & .. & .. & .. & .. & .. & .. & .. \\
\hline Agl..... & 3 & 121 & .. & .. & .. & .. & . & .. & . & .. \\
\hline
\end{tabular}

Group means

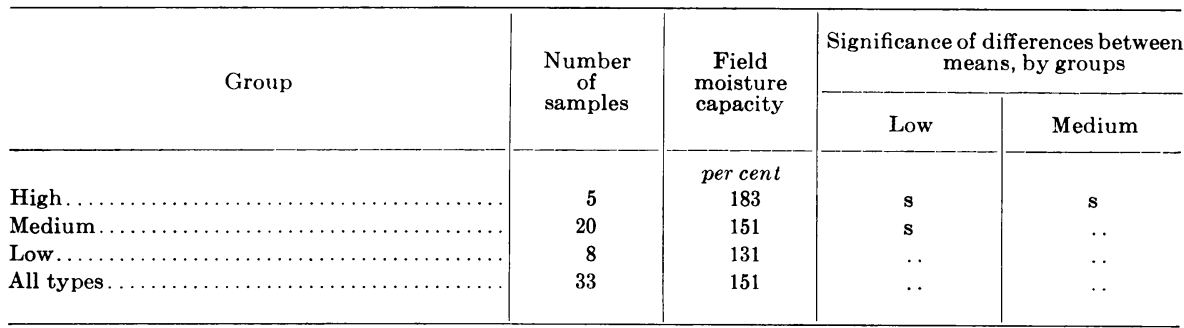

* Af, Adenostema fasciculatum, chamise

Agl, Arctostaphylos glandulosa Eastw., Eastwood manzanita

Ci, Ceanothus integerrimus, deer brush

Cl, C. leucodermis, chaparral whitethorn

Qc, Quercus chrysolepis, canyon live oak

Qw, Q. wislizenii, in terior live oak

Before separation of the mineral matter, the average was 75 per cent for both canyons. The correlation between percentages with and without mineral was too poorly defined to be useful.

Retention storage has more meaning in relation to precipitation and evaporation when it is expressed in depth of water. The conversion of percentages to depth by use of the formula, $d=1 / 100 M \rho_{a} D$, where $d$ is depth of water in inches, $M$ is per cent of moisture at field capacity, $\rho_{a}$ is volume weight, and $D$ is depth of forest floor in inches, introduces two factors, in addition to the percentage of moisture, which affect the depth of retention storage and may be related to it. The depth of retention storage $(d)$ is plot- 
ted over depth of forest floor $(D)$ in figure 4 , and the correlation is evident. The regression for Bell Canyon is $d=0.14 D+0.004$, and for Fern Canyon, $d=0.11 D+0.01$. Both regression coefficients are highly significant. However, estimates of retention storage from depth of floor by the use of these equations could be expected to give only rough approximations.

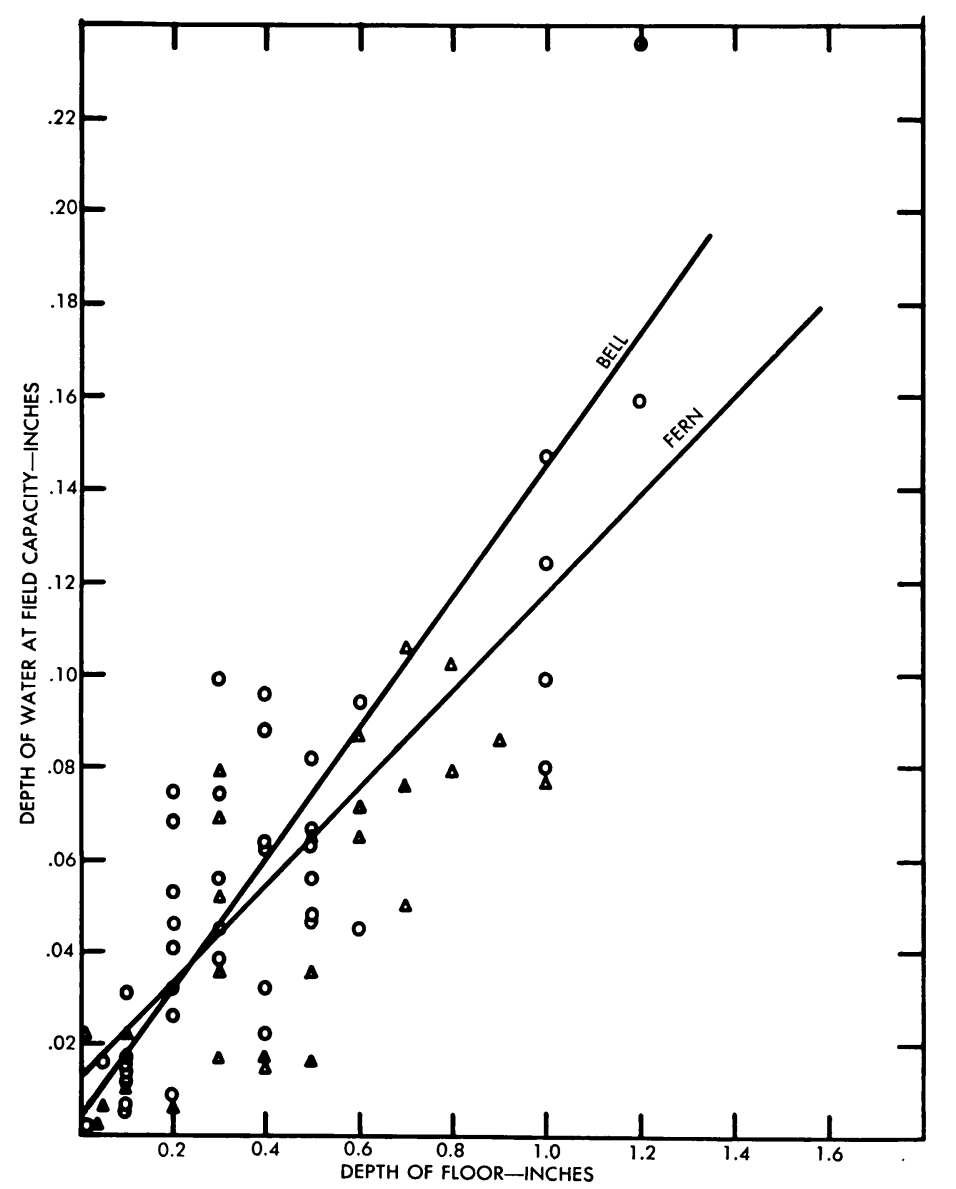

Fig. 4.-Relation of depth of retention storage at field capacity $(d)$ to depth of forest floor $(D)$. For Bell Canyon, $d=0.14 D+0.004$; for Fern Canyon, $d=0.11 D+0.01$.

As a result of introducing depth and volume weight of floor as factors in depth of retention storage, neither the sequence of types nor the composition of the groups, in tables 8 and 9 , is the same as it was on the basis of percentage field moisture capacity. In Bell Canyon, the medium group contains the types in which black sage $(\mathrm{Sm})$ or hoaryleaf ceanothus (Cer) is predominant, and the average of 0.06 inch retention storage differs from the averages of 0.20 for the high group and 0.02 for the low group with high significance. The low group contains chiefly the types in which chamise (Af) is predominant. Chamise floor has a low capacity to retain moisture 
TABLE 8

RETENTION STORAGE OF FOREST FLOOR IN 31-YEAR-OLD CHAPARRAL OF BELL CANYON

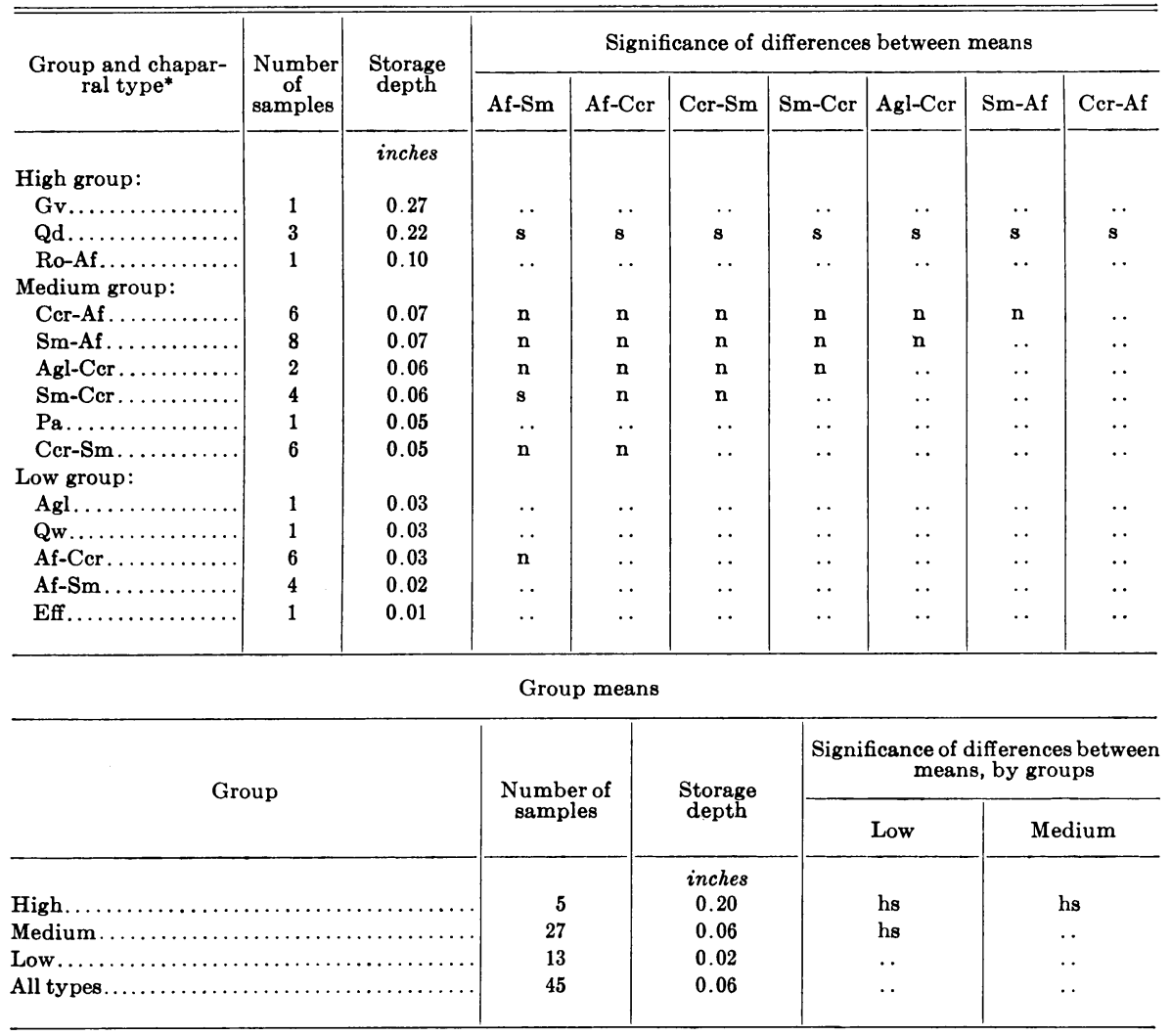

* Af, Adenostema fasciculatum, chamise

Agl, Arctostaphylos glandulosa Eastw., Eastwood manzanita

Ccr, Ceanothus crassifolius, hoaryleaf ceanothus

Eff, Eriogonum fasciculatum var. foliolosum, California buckwheat

Gv, Garrya veatchii, silktassel

Pa, Photinia arbutifolia, Christmasberry

Qd, Quercus dumosa, scrub oak

$Q w, Q$. wislizenii, interior live oak

Ro, Rhus ovata, sugarbush

Sm, Salvia mellifera, black sage

regardless of whether the retention is expressed as depth of water or as percentage of dry weight.

In Fern Canyon, deer brush ( $\mathrm{Ci}$ ) constitutes the high group, with retention storage of 0.07 inch depth of water. The live oaks characterize the medium group with retention storage of 0.05 inch. The low group, with storage of 0.02 inch, contains the mixtures of chaparral whitethorn ( $\mathrm{Cl}$ ), Eastwood manzanita (Agl), and chamise (Af). The only significant difference in mean retention storage among these groups is that between the low and the high. Combining all types, the 0.05 inch for the 11-year-old chaparral above 4,700 feet is only 0.01 inch lower than the 0.06 -inch depth for the 31-year-old chaparral below 3,500 feet. The 0.06-inch depth is closely 
comparable with the 0.08 inch at the 14 -year age (8). At the higher elevation, the 0.22-inch depth for the 50-year stand before the fire, as compared with the 0.05 inch 11 years after, reflects the change in amount of forest floor rather than in its retentive capacity. Only light rains or small fractions of heavier rains are retained by the forest floor. Because the retention stor-

TABLE 9

RETENTION STORAGE OF FOREST FLOOR IN 11-YEAR-OLD CHAPARRAL OF FERN CANYON

\begin{tabular}{|c|c|c|c|c|c|c|c|c|c|}
\hline \multirow{2}{*}{$\begin{array}{l}\text { Group and chapar- } \\
\text { ral type* }\end{array}$} & \multirow{2}{*}{$\begin{array}{c}\text { Number } \\
\text { of } \\
\text { samples }\end{array}$} & \multirow{2}{*}{$\begin{array}{l}\text { Storage } \\
\text { depth }\end{array}$} & \multicolumn{7}{|c|}{ Significance of differences between means } \\
\hline & & & $\mathrm{Cl}$ & Agl-Cl & $\mathrm{Af}-\mathrm{Cl}$ & $\mathrm{Qc}-\mathrm{Ci}$ & Qc & Agl & Qw \\
\hline & & inches & & & & & & & \\
\hline $\begin{array}{r}\text { High group: } \\
\mathrm{Ci} \ldots \ldots \ldots\end{array}$ & & & & & & & & & \\
\hline $\begin{array}{r}\mathrm{Ci} \ldots \ldots \ldots \ldots \\
\text { Medium group: }\end{array}$ & 7 & 0.07 & $\mathbf{8}$ & s & $\mathbf{s}$ & $\mathbf{n}$ & $\mathbf{n}$ & $\mathbf{n}$ & $\mathbf{n}$ \\
\hline $\begin{array}{l}\text { Medium group: } \\
\text { Qw.............. }\end{array}$ & & & & & & & & & \\
\hline $\begin{array}{c}\mathrm{Qw} \ldots \ldots \ldots \ldots \ldots \ldots \ldots \ldots \\
\mathbf{A g l} \ldots \ldots \ldots \ldots \ldots\end{array}$ & 3 & 0.06 & $\mathbf{n}$ & $\mathbf{n}$ & $\mathbf{n}$ & $\mathbf{n}$ & $\mathbf{n}$ & $\mathbf{n}$ & .. \\
\hline $\begin{array}{l}\mathrm{Agl} \ldots \ldots \ldots \ldots \ldots \ldots \\
\mathrm{Qc}-\mathrm{Qw} \ldots \ldots \ldots \ldots \ldots\end{array}$ & 3 & 0.06 & $\mathbf{n}$ & $\mathbf{n}$ & $\mathbf{n}$ & $\mathbf{n}$ & $\mathbf{n}$ & . & . \\
\hline $\begin{array}{l}\mathrm{Qc}-\mathrm{Qw} \ldots \ldots \ldots \ldots \ldots \\
\mathrm{Qc} \ldots \ldots \ldots \ldots \ldots \ldots\end{array}$ & 1 & 0.05 & . & .. & . & . & .. & . & $\cdots$ \\
\hline $\begin{array}{l}\text { Qc......... } \\
\text { Qc-Ci.... }\end{array}$ & 9 & 0.05 & $\mathbf{n}$ & $\mathbf{n}$ & $\mathbf{n}$ & $\mathbf{n}$ & . & $\cdots$ & . \\
\hline $\begin{array}{l}\text { Qc-Ci...... } \\
\text { Low group: }\end{array}$ & 3 & 0.03 & $\mathbf{n}$ & $\mathbf{n}$ & $\mathbf{n}$ & $\mathbf{n}$ & .. & .. & . \\
\hline $\begin{array}{l}\text { Low group: } \\
\text { Af-Cl..... }\end{array}$ & & & & & & & & & \\
\hline Af-Cl $\ldots \ldots \ldots \ldots$ & 2 & 0.03 & $\mathbf{n}$ & $\mathbf{n}$ & .. & .. &. & $\cdots$ & $\cdots$ \\
\hline Agl-Cl $\ldots \ldots \ldots \ldots$ & 2 & 0.03 & $\mathbf{n}$ & $\cdots$ & . & .. & $\cdots$ & . & $\cdots$ \\
\hline $\mathrm{Cl} \ldots \ldots \ldots \ldots \ldots$ & 2 & 0.02 & . & . & .. & .. & $\cdots$ & . & . \\
\hline Cl-Agl. ........... & 1 & 0.002 & .. & . & .. & $\cdots$ & . & .. & .. \\
\hline
\end{tabular}

Group means

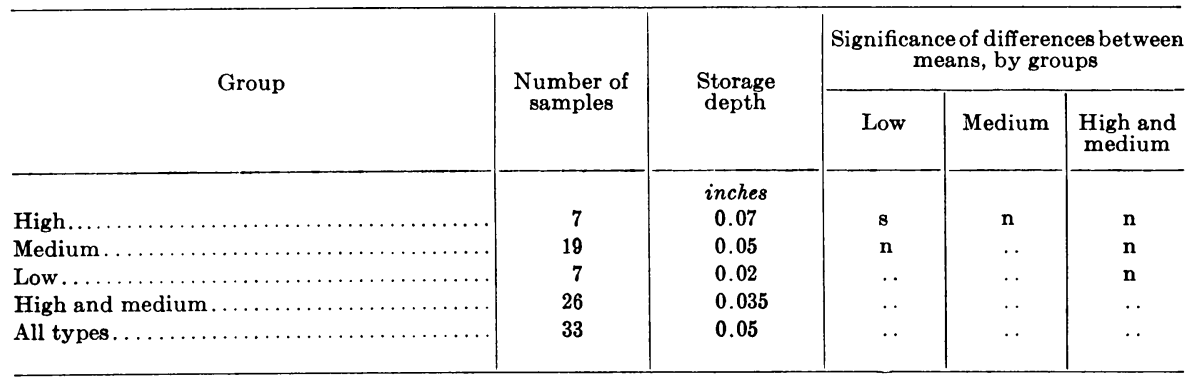

* Af, Adenostema fasciculatum, chamise

Agl, Arctostaphylos glandulosa Eastw., Eastwood manzanita

Ci, Ceanothus integerrimus, deer brush

Cl, C. leucodermis, chaparral whitethorn

Qc, Quercus chrysolepis, canyon live oak

$\mathrm{Qw}, Q$. wislizenii, interior live oak

age water does not contribute to streamflow or human use, the amount so lost should be kept as small as possible. From this point of view, chaparral whitethorn ( $\mathrm{Cl}$ ), chamise (Af), and perhaps Eastwood manzanita (Agl) are the most desirable species. On the other hand, a layer of litter shields the soil from the impact of raindrops, and reduces losses by evaporation from the mineral soil. The deeper the forest floor, up to a certain point, the greater is the reduction. Thus with conflicting considerations, a general statement as to over-all relative desirability of different species is not justified.

Annual Accumulation of Litter.-The amount of litter that falls from the chaparral each year from May through the following April differs from 
the total forest floor in that it is independent of the processes of decomposition that take place in the floor over a period of years. Hence it should be more nearly related to the chaparral cover and its changes in composition, density, and age. Table 10 shows the means of annual accumulation of litter in Bell Canyon, by types and years, for the period 1935-53. The 19-year

TABLE 10

MEANS OF ANNUAL ACCUMULATION OF LITTER IN BELL CANYON, BY TYPES* AND YEARS

\begin{tabular}{|c|c|c|c|c|c|c|c|c|c|c|c|c|}
\hline \multirow{3}{*}{ Year } & \multicolumn{12}{|c|}{ Types of chaparral } \\
\hline & Gv & Ccr-Ag & Af-Ccr & Cer & Agl & Qd-Cer & Af-Sm & $\mathrm{Qw}$ & Sm-Cer & Ccr-Af & Cer-Sm & Sm-Af \\
\hline & \multicolumn{12}{|c|}{ metric tons per acre } \\
\hline $1935 \ldots$ & 0.09 & 1.29 & 0.83 & 0.69 & $\ldots$ & 0.66 & 0.30 & 0.30 & 0.55 & 0.62 & 0.83 & 0.50 \\
\hline $1936 \ldots$ & 1.14 & 2.00 & 1.69 & 1.28 & $\ldots$ & 1.33 & 0.61 & 0.69 & 1.15 & 1.24 & 1.10 & 0.44 \\
\hline $1937 \ldots$ & $\ldots$ & 1.35 & 0.97 & 1.18 & $\ldots$ & 0.84 & 0.54 & 0.55 & 0.62 & 0.82 & 0.92 & 0.72 \\
\hline $1938 \ldots$ & $\ldots$ & 1.22 & 1.11 & 1.07 & $\ldots$ & 0.84 & 0.53 & 0.74 & $\ldots$ & 1.13 & 0.78 & 0.35 \\
\hline $1939 \ldots$ & 1.39 & 1.41 & 1.30 & 1.42 & $\ldots$ & 1.15 & 0.70 & 0.92 & 1.50 & 1.37 & 0.94 & 0.77 \\
\hline $1940 \ldots$ & 1.43 & 0.90 & 0.83 & 1.94 & 1.27 & 0.82 & 0.71 & 1.15 & 1.07 & 0.90 & 0.83 & 0.88 \\
\hline $1941 \ldots$ & $\ldots$ & 0.66 & 1.21 & 1.43 & 0.66 & 0.75 & 0.68 & 0.74 & 0.78 & 0.39 & 0.63 & 0.68 \\
\hline $1942 \ldots$ & $\cdots$ & 0.70 & 1.39 & 1.29 & 0.96 & 1.16 & 0.99 & $\ldots$ & 0.87 & 1.01 & 1.23 & 0.52 \\
\hline 1943. & 1.42 & 1.25 & 1.28 & 1.18 & 0.78 & 1.01 & 0.95 & 1.03 & 1.24 & 0.90 & 0.96 & 0.73 \\
\hline $1944 \ldots$ & 1.58 & 0.59 & 1.26 & 1.06 & 1.28 & 0.98 & 0.91 & 1.28 & 1.14 & 0.80 & 0.76 & 0.42 \\
\hline 1945 . & 1.63 & 0.80 & 1.12 & 1.37 & 0.71 & 1.82 & 1.09 & 1.49 & 0.96 & 0.85 & 0.64 & 0.70 \\
\hline $1946 \ldots$ & 1.47 & 1.48 & 1.23 & 1.17 & 1.14 & 1.08 & 1.42 & 1.21 & 1.08 & 1.05 & 0.51 & 0.64 \\
\hline 1947. & 1.20 & 1.09 & 1.19 & 1.46 & 0.94 & 0.85 & 1.75 & 1.08 & 0.96 & 0.91 & 0.65 & 0.44 \\
\hline $1948 \ldots$ & 1.68 & 1.55 & 1.12 & 1.10 & 0.77 & 1.10 & 0.91 & 0.82 & 0.83 & 0.96 & 0.63 & 0.81 \\
\hline $1949 \ldots$ & 1.13 & 1.28 & 1.38 & 1.12 & 1.03 & 1.09 & 1.12 & 1.08 & 1.15 & 0.98 & 1.08 & 0.81 \\
\hline $1950 \ldots$ & 0.99 & 1.14 & 0.93 & 0.78 & 0.80 & 0.75 & 0.96 & 0.72 & 0.78 & 0.80 & 0.71 & 0.80 \\
\hline $1951 \ldots$ & 1.01 & 1.61 & 1.22 & 0.87 & 1.44 & 0.86 & 1.25 & 1.12 & 0.81 & 0.73 & 0.44 & 0.53 \\
\hline $1952 \ldots$ & 1.60 & 1.17 & 0.92 & 0.79 & $\ldots$ & 0.62 & 1.03 & 1.02 & 0.78 & 0.95 & 0.59 & 0.49 \\
\hline $1953 \ldots$ & 1.61 & 1.03 & 0.77 & 0.51 & 1.24 & 1.26 & 1.67 & 1.01 & 0.64 & 0.51 & 0.63 & 0.42 \\
\hline $\begin{array}{r}19-\text { year } \\
\text { mean }\end{array}$ & 1.29 & 1.19 & 1.14 & 1.14 & 1.00 & 0.99 & 0.95 & 0.94 & 0.94 & 0.89 & 0.78 & 0.61 \\
\hline
\end{tabular}

* Af, Adenostema fasciculatum, chamise

Agl, Arctostaphylos glandulosa Eastw., Eastwood manzanita

Ccr, Ceanothus crassifolius, hoaryleaf ceanothus

Eff, Eriogonum fasciculatum var. foliolosum, California buckwheat

Gv, Garrya veatchii, silktassel

$\mathrm{Pa}$, Photinia arbutifolia, Christmasberry

Qd, Quercus dumosa, scrub oak

$Q w, Q$. wislizenii, interior live oak

Ro, Rhus ovata, sugarbush

Sm, Salvia mellifera, black sage

means for each type are also given. The large variations in successive years in the same type are evident. Presumably they are associated with changes in growing conditions, but since the changes from one year to the next, in different types, are frequently in opposite directions, consistent explanations are precluded. However, in two of the types, chamise (Af)-black sage $(\mathrm{Sm})$ and interior live oak $(\mathrm{Qw})$, for the 11 years from 1935 to 1946, the dry weights of annual accumulation increased linearly with age at rates of 0.07 and 0.08 metric tons per acre per year, respectively, but after 1946 the Af-Sm leveled off and the $\mathrm{Qw}$ decreased (fig. 5). It is not obvious whether the age of 27 years in 1946 represented culmination of the curve 


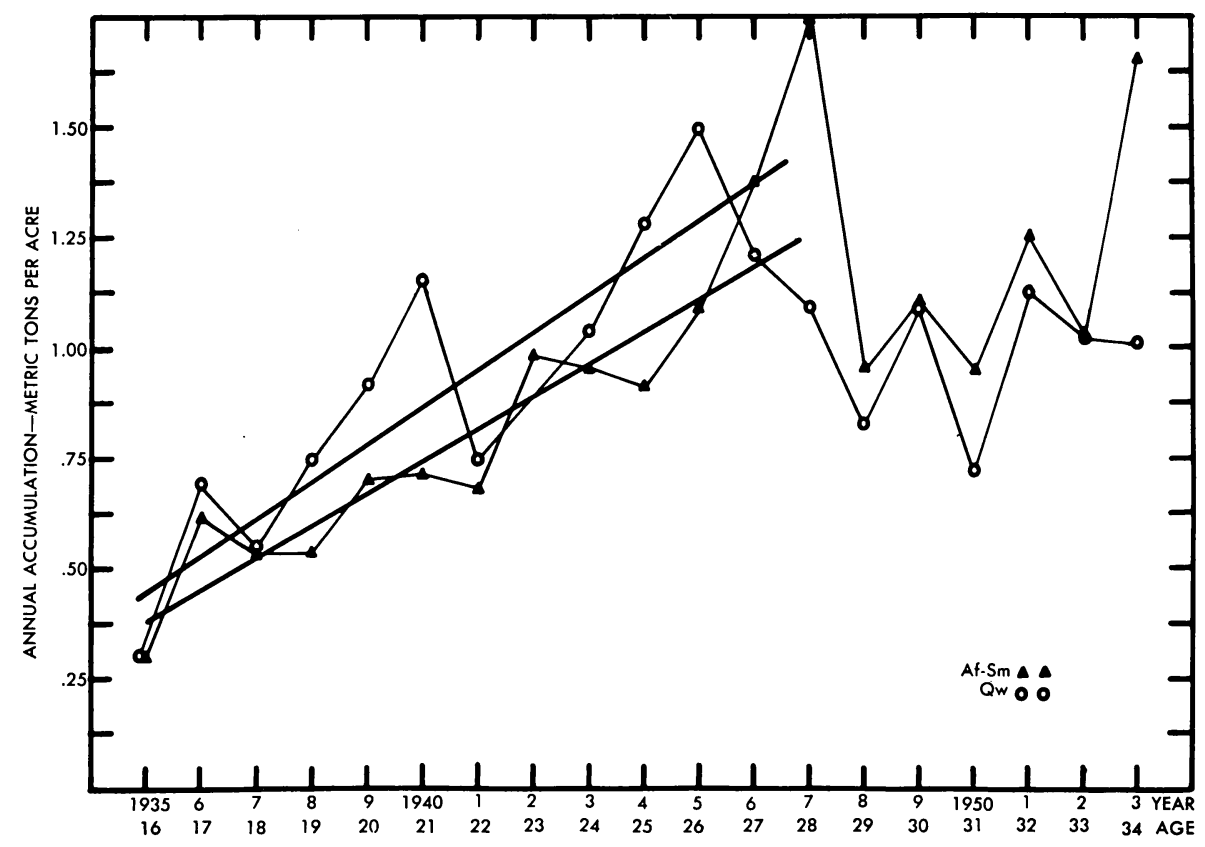

Fig. 5.-Trends of annual accumulation of litter with age in the chamise (Af)-black sage $(\mathrm{Sm})$ and interior live oak $(\mathrm{Qw})$ types of Bell Canyon.

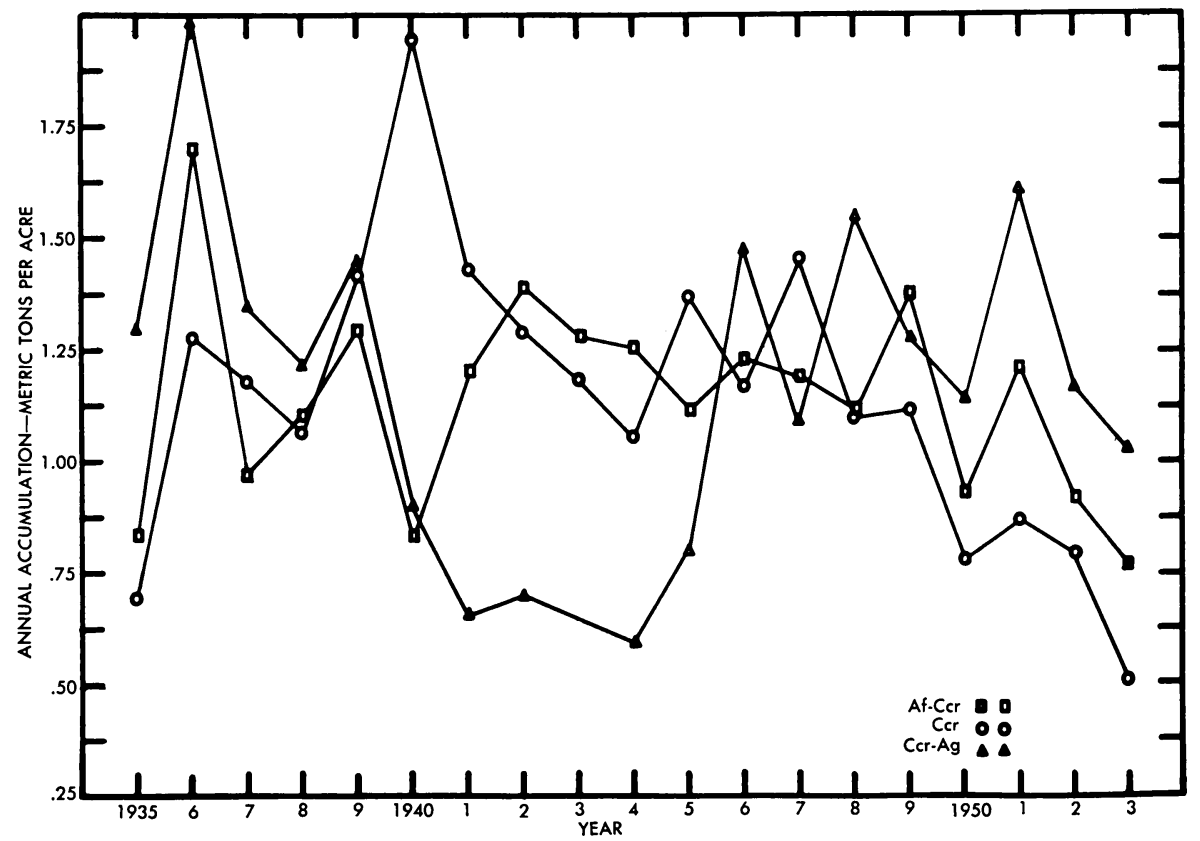

Fig. 6.-High annual accumulations of litter, by years, of chamise (Af)-hoaryleaf ceanothus (Cer), pure hoaryleaf ceanothus (Ccr), and hoaryleaf ceanothus (Ccr)-Eastwood manzanita $(\mathrm{Agl})$ in Bell Canyon. 


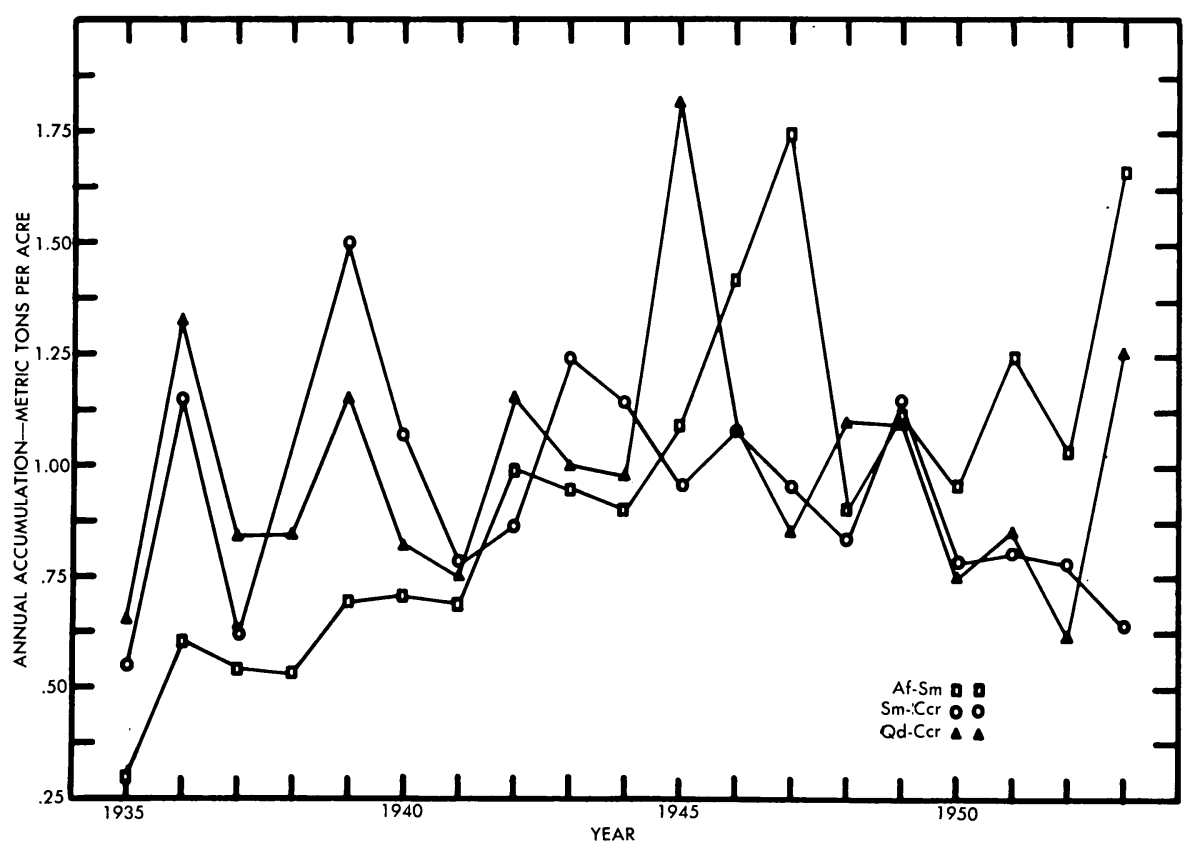

Fig. 7.-Medium annual accumulations of litter, by years, of chamise (Af)-black sage $(\mathrm{Sm})$, black sage (Sm)-hoaryleaf ceanothus (Ccr), and California scrub oak (Qd) - hoaryleaf ceanothus (Cer) in Bell Canyon.

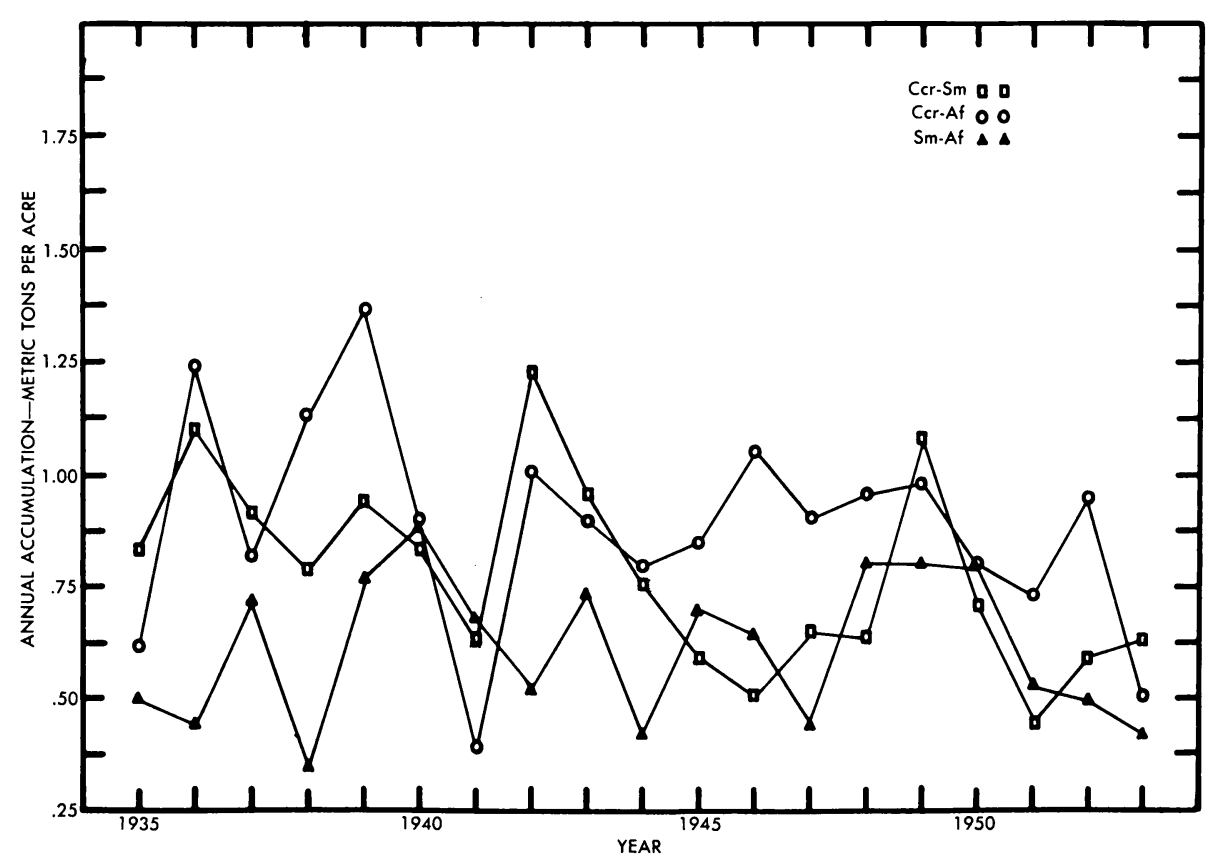

Fig. 8.-Low annual accumulations of litter, by years, of hoaryleaf ceanothus (Cer)black sage $(\mathrm{Sm})$, hoaryleaf ceanothus (Ccr)-chamise (Af), and black sage (Sm)-chamise (Af) in Bell Canyon. 
TABLE 11

ANNUAL ACCUMULATION OF LITTER BY CHAPARRAL TYPES IN BELL CANYON, 1935-1953

\begin{tabular}{|c|c|c|c|c|c|c|c|c|c|c|c|c|c|c|c|}
\hline \multirow{2}{*}{$\begin{array}{l}\text { Group } \\
\text { and chaparral } \\
\text { type* }\end{array}$} & \multirow{2}{*}{$\begin{array}{c}\text { Number } \\
\text { of } \\
\text { samples }\end{array}$} & \multirow{2}{*}{$\begin{array}{c}\text { Average } \\
\text { annual } \\
\text { accumula- } \\
\text { tion } \\
\text { per acre }\end{array}$} & \multicolumn{11}{|c|}{ Significance of differences between means } & \multirow{2}{*}{$\begin{array}{l}\text { Average } \\
\text { floor } \\
\text { per acre }\end{array}$} & \multirow{2}{*}{$\begin{array}{l}\text { Ratio } \\
\text { of total to } \\
\text { annual } \\
\text { accumula- } \\
\text { tion }\end{array}$} \\
\hline & & & $\begin{array}{l}\text { Sm- } \\
\text { Af }\end{array}$ & $\begin{array}{l}\text { Ccr- } \\
\text { Sm }\end{array}$ & $\begin{array}{l}\text { Ccr- } \\
\text { Af }\end{array}$ & $\begin{array}{l}\text { Sm- } \\
\text { Ccr }\end{array}$ & Qw & Af- & $\begin{array}{l}\text { Qd- } \\
\text { Ccr }\end{array}$ & $\mathrm{Agl}$ & Cer & $\begin{array}{l}\text { Af- } \\
\text { Ccr }\end{array}$ & $\begin{array}{l}\text { Ccr- } \\
\text { Agl }\end{array}$ & & \\
\hline & & $\begin{array}{c}\text { metric } \\
\text { tons }\end{array}$ & & & & & & & & & & & & $\begin{array}{c}\text { metric } \\
\text { tons }\end{array}$ & \\
\hline \multicolumn{16}{|l|}{ High group: } \\
\hline Gv....... & 17 & 1.29 & hs & hs & hs & $\mathbf{n}$ & $\mathbf{s}$ & $\mathbf{s}$ & $\mathbf{s}$ & $\mathbf{s}$ & $\mathbf{n}$ & $\mathbf{n}$ & $\mathbf{n}$ & 14.1 & 10.9 \\
\hline Ccr-Agl.... & 43 & 1.19 & hs & hs & $\mathbf{s}$ & $\mathbf{n}$ & $\mathbf{s}$ & $\mathbf{n}$ & $\mathbf{n}$ & $\mathrm{n}$ & $\mathbf{n}$ & $\mathrm{n}$ & .. & 5.5 & 4.6 \\
\hline Af-Cer $\ldots \ldots \ldots$ & 145 & 1.14 & hs & hs & $\mathbf{s}$ & hs & $\mathbf{s}$ & $\mathrm{n}$ & hs & $\mathbf{n}$ & $\mathbf{n}$ & .. & .. & 3.0 & 2.6 \\
\hline Cer.......... & 75 & 1.14 & hs & hs & $\mathbf{s}$ & $\mathbf{n}$ & $\mathbf{n}$ & $\mathbf{n}$ & $\mathbf{s}$ & $\mathrm{n}$ & .. & .. & .. & 5.1 & 4.5 \\
\hline \multicolumn{16}{|l|}{ Medium group: } \\
\hline Agl $\ldots \ldots \ldots$ & 14 & 1.00 & $\mathbf{s}$ & $\mathbf{n}$ & $\mathbf{n}$ & $\mathbf{n}$ & $\mathrm{n}$ & $\mathbf{n}$ & $\mathbf{n}$ & .. & .. & .. & . & 2.7 & 2.7 \\
\hline Qd-Ccr....... & 47 & 0.99 & $\mathbf{s}$ & s & $\mathrm{n}$ & $\mathbf{n}$ & n & $\mathrm{n}$ & . & . & . & . & . & 17.7 & 17.9 \\
\hline Af-Sm... & 78 & 0.95 & s & $\mathrm{n}$ & $\mathbf{n}$ & $\mathbf{n}$ & $\mathrm{n}$ & .. & .. & . & . & . & . & 2.3 & 2.4 \\
\hline $\mathrm{Qw} \ldots \ldots . .$. & 18 & 0.94 & s & $\mathbf{n}$ & $\mathbf{n}$ & $\mathbf{n}$ & .. & .. & .. & .. & . & . & .. & 2.9 & 3.1 \\
\hline Sm-Cer.. & 63 & 0.94 & s & s & $\mathbf{n}$ & .. & .. & .. & .. & .. & . & .. & .. & 4.5 & 4.8 \\
\hline Cer-Af... & 126 & 0.89 & hs & $\mathbf{n}$ & .. & .. & .. & .. & .. & .. & .. & .. & .. & 5.1 & 5.7 \\
\hline \multicolumn{16}{|l|}{ Low group: } \\
\hline Ccr-Sm. . & 92 & 0.78 & $\mathbf{n}$ & .. & .. & .. & .. & .. & .. & .. & .. & . & .. & 4.1 & 5.3 \\
\hline Sm-Af........ & 37 & 0.61 & . & . & .. & .. & . & . & . & . & . & . & . & 4.8 & 7.9 \\
\hline
\end{tabular}

Group means

\begin{tabular}{|c|c|c|c|c|}
\hline Group & $\begin{array}{l}\text { Number } \\
\text { of } \\
\text { samples }\end{array}$ & $\begin{array}{c}\text { Average annual } \\
\text { accumulation } \\
\text { per acre }\end{array}$ & \multicolumn{2}{|c|}{$\begin{array}{c}\text { Significance of differences between } \\
\text { means, by groups }\end{array}$} \\
\hline 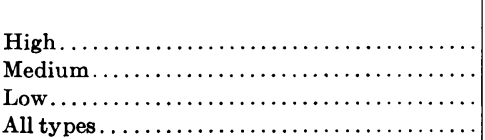 & $\begin{array}{l}280 \\
346 \\
129 \\
755\end{array}$ & $\begin{array}{l}\text { metric tons } \\
1.16 \\
0.93 \\
0.73 \\
0.98\end{array}$ & $\begin{array}{l}\text { hs } \\
\mathbf{8} \\
\cdots \\
\cdots\end{array}$ & $\begin{array}{l}\mathbf{s} \\
\cdots \\
\cdots \\
\cdots\end{array}$ \\
\hline
\end{tabular}

* Af, Adenostema fasciculatum, chamise

Agl, Arctostaphylos glandulosa Eastw., Eastwood manzanita

Ccr, Ceanothus crassifolius, hoaryleaf ceanothus

Eff, Eriogonum fasciculatum var. foliolosum, California buckwheat

Gv, Garrya veatchii, silktassel

Pa, Photinia arbutifolia, Christmasberry

Qd, Quercus dumosa, scrub oak

Qw, Q. wislizenii, interior live oak

Ro, Rhus ovata, sugarbush

Sm, Salvia mellifera, black sage

of current annual growth or whether the changes in trend were associated with the four very dry years (beginning with the water year of 1947-48) that followed the series of favorable years from 1935 through 1946. The irregular fluctuations and lack of trends in annual accumulation for different types are evident in figures 6,7 , and 8 , which show graphically the data of table 10. Each figure gives data for three types, the means of which do not differ significantly. The tendency toward decreasing trends, in the years following 1948, in the types in which hoaryleaf ceanothus (Cer) was predominant may reflect the heavy mortality of that species in recent years. The maximum accumulation in any one year was the 2.0 metric tons per acre in the hoaryleaf ceanothus (Cer)-Eastwood manzanita (Agl) type in 
TABLE 12

MEANS OF ANNUAL ACCUMULATION OF LITTER IN FERN CANYON, BY YEARS AND TYPES*

\begin{tabular}{|c|c|c|c|c|c|c|c|c|c|c|c|c|c|c|}
\hline \multirow{3}{*}{ Year } & \multicolumn{14}{|c|}{ Types of chaparral } \\
\hline & $\mathrm{Ag}-\mathrm{Cl}$ & Qc & $\begin{array}{c}\mathrm{Qc} \\
\text { (old) }\end{array}$ & $\mathrm{Agl}$ & Qw & $\mathrm{Ci}$ & $\mathrm{Cl}-\mathrm{Ag}$ & Ag-Af & $\mathrm{Ag}$ & $\underset{\mathrm{Cl}}{\mathrm{Agl}}$ & Qw-Cl & Qc-Qw & Qc-Pm & Af \\
\hline & \multicolumn{14}{|c|}{ metric tons per acre } \\
\hline 1935. & 1.01 & 0.51 & $\ldots$ & 0.91 & 0.72 & $\ldots$ & 0.38 & 1.51 & 1.67 & 1.55 & 0.89 & 0.52 & 0.35 & 0.14 \\
\hline 1936 . & 1.06 & 0.72 & $\ldots$ & 1.24 & 0.73 & $\ldots$ & 0.59 & 2.18 & 2.26 & 1.38 & 1.45 & 0.88 & 0.40 & 0.25 \\
\hline 1937. & 1.15 & 0.56 & $\ldots$ & 1.21 & 0.79 & $\ldots$ & 0.55 & 1.70 & 0.88 & 1.21 & 1.15 & 0.78 & 0.24 & 0.24 \\
\hline 1938 & 1.15 & 0.66 & $\cdots$ & 1.16 & 0.71 & $\cdots$ & 0.31 & 1.85 & 1.05 & 1.40 & 0.91 & 0.87 & 0.48 & 0.22 \\
\hline
\end{tabular}

After the fire of late 1938

\begin{tabular}{|c|c|c|c|c|c|c|c|c|c|c|c|c|c|c|}
\hline \multirow{3}{*}{ Year } & \multicolumn{14}{|c|}{ Types of chaparral } \\
\hline & $\mathrm{Ag}-\mathrm{Cl}$ & $\mathrm{Qc}$ & $\begin{array}{c}\mathrm{Qc} \\
\text { (old) }\end{array}$ & Agl & Qw & $\mathrm{Ci}$ & $\mathrm{Cl}-\mathrm{Ag}$ & $\mathrm{Cl}$ & $\mathrm{Ag} \dagger$ & $\stackrel{\mathrm{Agl}-}{\mathrm{Cl}+}$ & $\begin{array}{l}\text { Qw- } \\
\text { Clt }\end{array}$ & $\begin{array}{c}\text { Qc- } \\
\text { Qw† }\end{array}$ & $\begin{array}{c}\text { Qc- } \\
\text { Pmt }\end{array}$ & Aft \\
\hline & \multicolumn{14}{|c|}{ metric tons per acre } \\
\hline $1940 \ldots$ & $\ldots$ & 0.33 & $\ldots$ & 0.20 & 0.56 & 0.14 & 0.10 & $\ldots$ & $\ldots$ & $\ldots$ & $\ldots$ & & & \\
\hline $1941 \ldots$ & $\ldots$ & 0.34 & 2.59 & 0.23 & 0.45 & 0.10 & 0.15 & & & . . & $\ldots$ & & $\ldots$ & \\
\hline 1942. & $\ldots$ & 0.42 & & 0.48 & 0.52 & 0.17 & 0.25 & $\ldots$ & $\ldots$ & $\ldots$ & $\ldots$ & $\ldots$ & $\ldots$ & $\ldots$ \\
\hline 1943. & $\ldots$ & 0.48 & 1.71 & 0.51 & 0.53 & 0.15 & 0.20 & $\ldots$ & $\ldots$ & $\ldots$ & $\ldots$ & & $\ldots$ & $\ldots$ \\
\hline $1944 .$. & $\ldots$ & 0.51 & 1.96 & 0.63 & 0.72 & 0.24 & 0.21 & $\ldots$ & $\ldots$ & $\ldots$ & $\ldots$ & & $\ldots$ & $\ldots$ \\
\hline 1945. & $\ldots$ & 0.77 & 2.75 & 0.40 & 0.90 & 0.48 & 0.26 & & & $\ldots$ & $\ldots$ & & $\ldots$ & $\ldots$ \\
\hline $1946 .$. & $\ldots$ & 0.78 & 2.15 & 1.32 & 0.65 & 0.63 & 0.26 & & & $\cdots$ & $\cdots$ & $\cdots$ & $\cdots$ & $\cdots$ \\
\hline $1947 \ldots$ & $\ldots$ & 0.84 & 1.82 & 1.34 & 0.83 & 0.55 & 0.22 & $\ldots$ & & $\ldots$ & $\ldots$ & $\ldots$ & $\ldots$ & $\ldots$ \\
\hline $1948 \ldots \ldots \ldots$ & $\ldots$ & 0.81 & 1.63 & 0.81 & 0.87 & 0.69 & 0.35 & $\ldots$ & $\ldots$ & $\ldots$ & $\ldots$ & $\ldots$ & $\ldots$ & $\ldots$ \\
\hline $1949 \ldots \ldots \ldots$ & 0.70 & 1.05 & 2.42 & 0.88 & 1.01 & 0.49 & 0.42 & 0.28 & $\ldots$ & $\ldots$ & $\ldots$ & $\ldots$ & $\ldots$ & $\ldots$ \\
\hline $1950 \ldots$ & 0.71 & 0.84 & 1.71 & 0.62 & 0.62 & 0.49 & 0.30 & 0.20 & & $\ldots$ & $\ldots$ & $\ldots$ & $\ldots$ & $\ldots$ \\
\hline $1951 \ldots$ & 1.00 & 1.07 & 2.03 & 0.97 & 0.83 & 0.56 & 0.37 & 0.37 & & $\ldots$ & $\ldots$ & $\ldots$ & $\ldots$ & $\ldots$ \\
\hline $1952 \ldots$ & 1.23 & 1.48 & 2.62 & 1.25 & 0.92 & 0.76 & 0.38 & 0.30 & $\ldots$ & $\ldots$ & $\ldots$ & $\ldots$ & $\ldots$ & $\cdots$ \\
\hline $1953 \ldots \ldots$ & 1.79 & 0.82 & 1.26 & 0.75 & 0.87 & 0.42 & 0.48 & 0.57 & $\ldots$ & $\ldots$ & $\ldots$ & $\ldots$ & $\ldots$ & $\ldots$ \\
\hline
\end{tabular}

* Af, Adenostema fasciculatum, chamise

Ag, Arctostaphylos glauca, bigberry manzanita

Agl, A. glandulosa Eastw., Eastwood manzanita

Agl, A. glandulosa Eastw., Eastwood man integerrimus, deer brush

$\mathrm{Cl}, \mathrm{C}$. leucodermis, chaparral whitethorn

Pm, Pseudotsuga macrocarpa, bigcone Douglas fir

Qc, Quercus chrysolepis, canyon live oak

Qw, Q. wislizenii, interior live oak

$\dagger$ Did not return after the fire.

1936. Maximums occurred in three of the types in 1936, and that year most nearly represented the year of maximum accumulation of any in the series. Similarly, 1935 was the year of minimum accumulation in five of the types and in any year of the series.

The mean annual accumulations by groups and types are summarized, for Bell Canyon, in descending sequence of dry weights together with significance of differences, in table 11. Many of the differences between types of the high and low groups are significant, and the 0.93 metric ton per acre of the medium group is significantly different from both the 1.16 of the high group and the 0.73 of the low. The general average for all types is 0.98 ton per acre per year. Types with Eastwood manzanita (Agl) and silktassel 
TABLE 13

ANNUAL ACCUMULATION OF LITTER BY CHAPARRAL TYPES IN FERN CANYON, 1935-1938

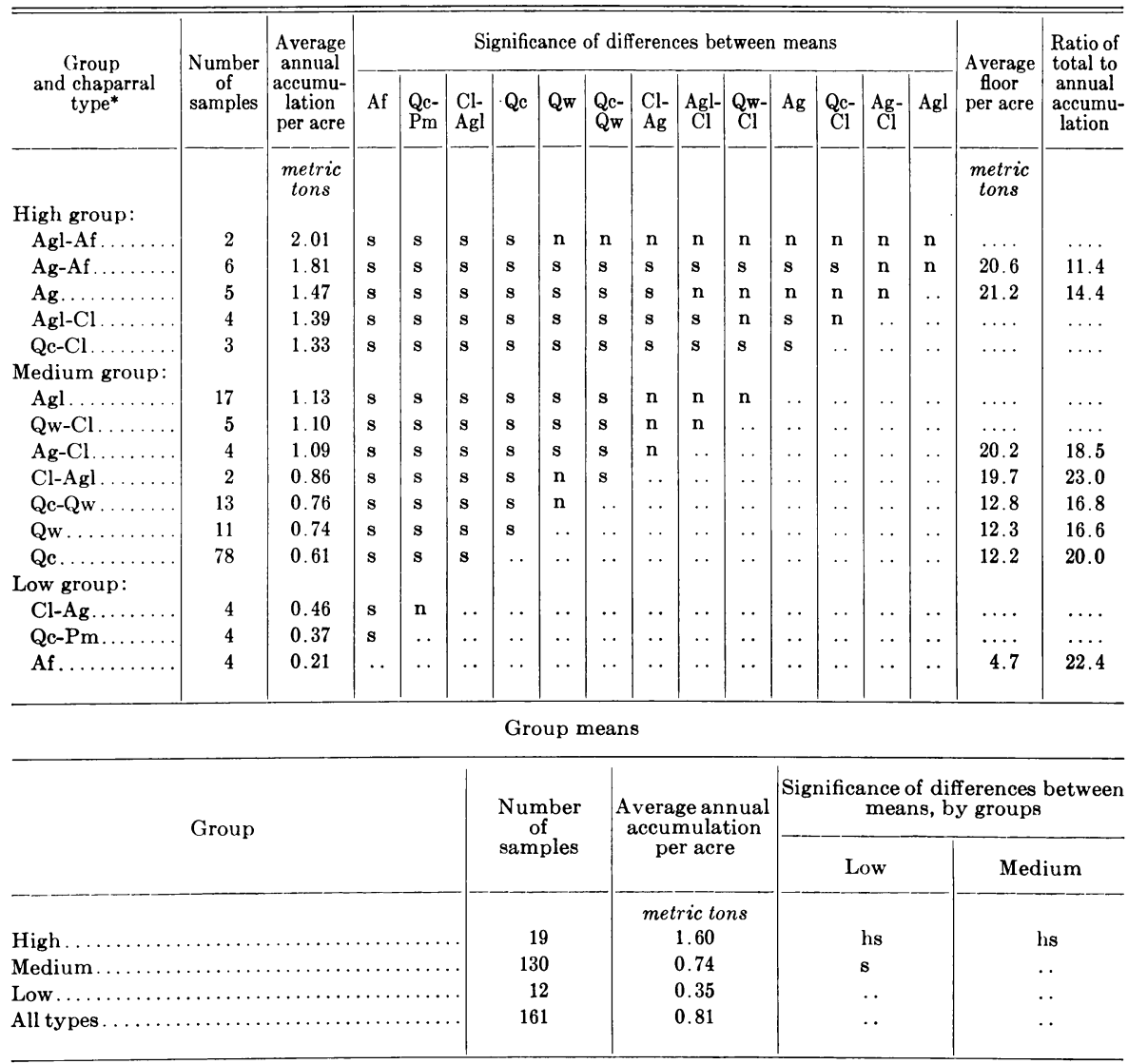

* Af, Adenostema fasciculatum, chamise

Agl, Arctostaphylos glandulosa Eastw., Eastwood manzanita

$\mathrm{Ci}$, Ceanothus integerrimus, deer brush

Cl, C. leucodermis, chaparral whitethorn

Pm, Pseudotsuga macrocarpa, bigcone Douglas fir

Qc, Quercus chrysolepis, canyon live oak

$\mathrm{Qw}, \mathrm{Q}$. wislizenii, interior live oak

(Gv) tend to have large annual accumulations of litter, and types with black sage $(\mathrm{Sm})$ tend to have small ones. Hoaryleaf ceanothus (Cer) and chamise (Af) mixtures occur in all three groups.

In Fern Canyon, the means of annual accumulation by years (table 12) have to be considered separately for the period 1935-38, before the fire, when the chaparral was over 50 years old, and for the first 14 years after the fire as the chaparral developed. In the first period, the variations between years and the tendency for 1935 to be the low and 1936 the high year for all types are evident. In chaparral of this age it is unlikely that there would be a noticeable trend with increasing age even if a longer series 
of records were available. The differences between types are shown more clearly in table 13 where the means for the four years are arranged in descending sequence.

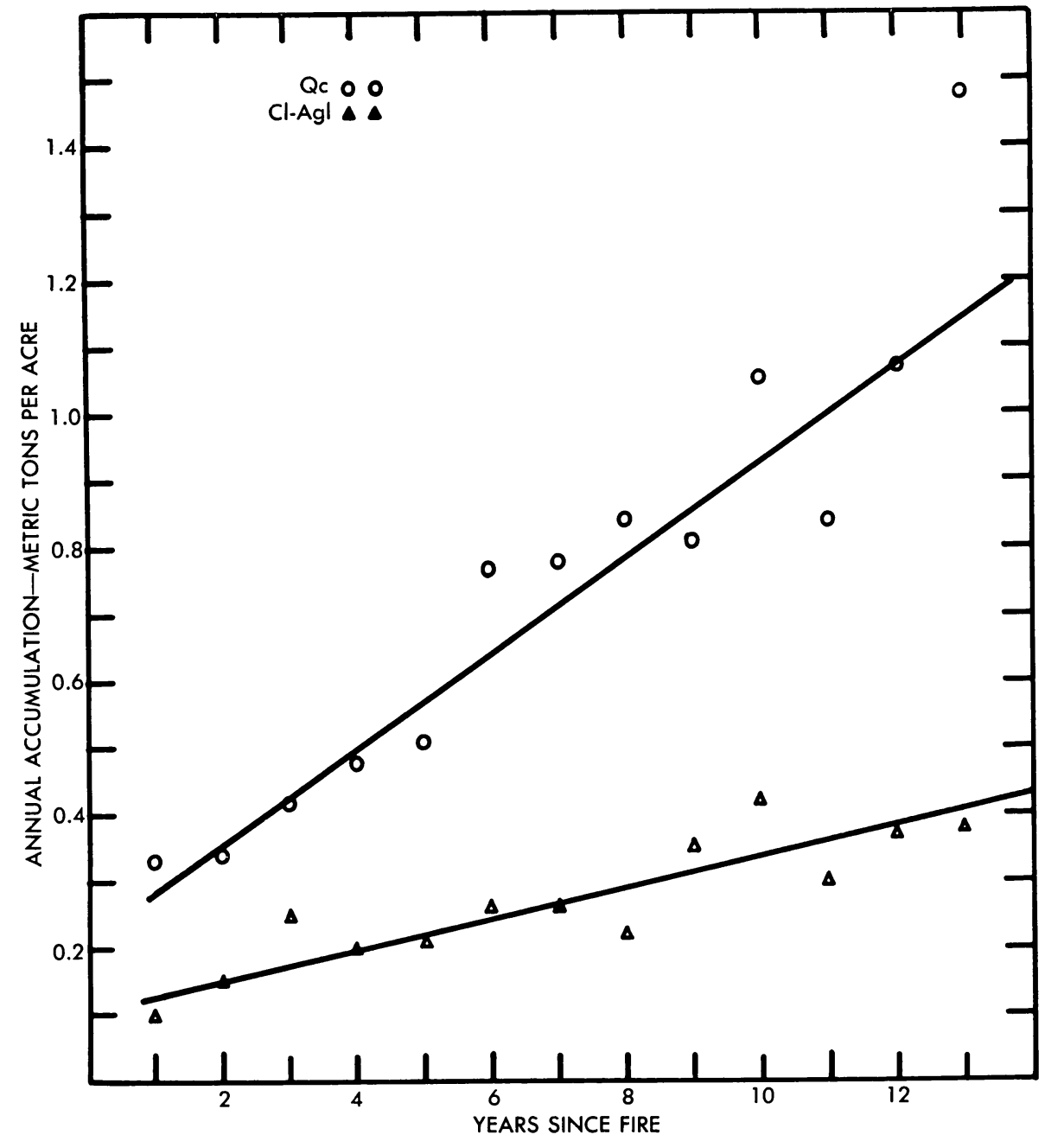

Fig. 9.-Trends of annual accumulation of litter $(W)$ with years since fire $(T)$ in Fern Canyon. In the canyon live oak $(\mathrm{Qc}), W=0.07 T+0.22$; and in the chaparral whitethorn $(\mathrm{Cl})$-Eastwood manzanita $(\mathrm{Agl}), W=0.02 T+0.11$.

In the years after the fire, the irregular fluctuations in annual accumulation from year to year do not wholly obscure the trends of increase with age. The one exception is the column of figures for old canyon live oak (Qc), which represents a single sampling point directly under the crowns of a group of large trees which survived at least two fires and are probably more than 100 years old. The figures were included to show that there was no progressive change in annual accumulation in a stand that was well 


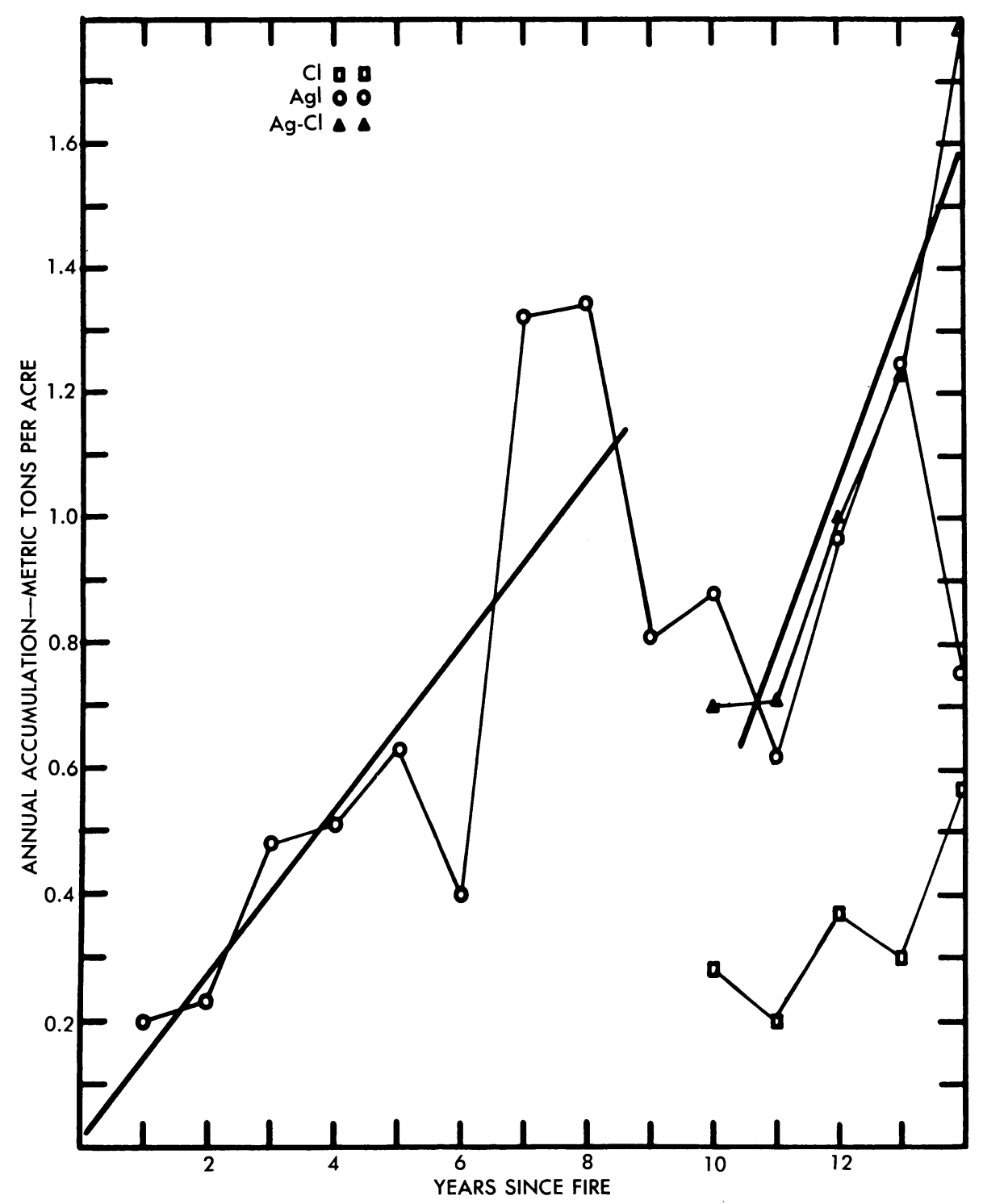

Fig. 10.- Trends of annual accumulation of litter with years since fire in the chaparral whitethorn ( $\mathrm{Cl})$, Eastwood manzanita ( $\mathrm{Agl}$ ), and bigberry manzanita ( $\mathrm{Ag}$ )-chaparral whitethorn types of Fern Canyon.

beyond the age of culmination of current growth and, consequently, that the rising trends in the young oak and other types could be attributed to growth with increasing age. The trends for canyon live oak and for chaparral whitethorn ( $\mathrm{Cl}$ )-Eastwood manzanita $(\mathrm{Agl})$ are well defined and linear for the 14-year period, and can be expressed as $W=0.07 T+0.22$ and $W=0.02 T+0.11$, respectively, where $W$ is metric tons per acre and $T$ is 
years (fig. 9). The regression coefficients indicate rates of increase of 0.07 and 0.02 metric ton per acre per year as the chaparral increased in size and density. For interior live oak $(\mathrm{Qw})$, the rate of increase is 0.06 metric ton per acre for the first 10 years, but thereafter the trend no longer rises

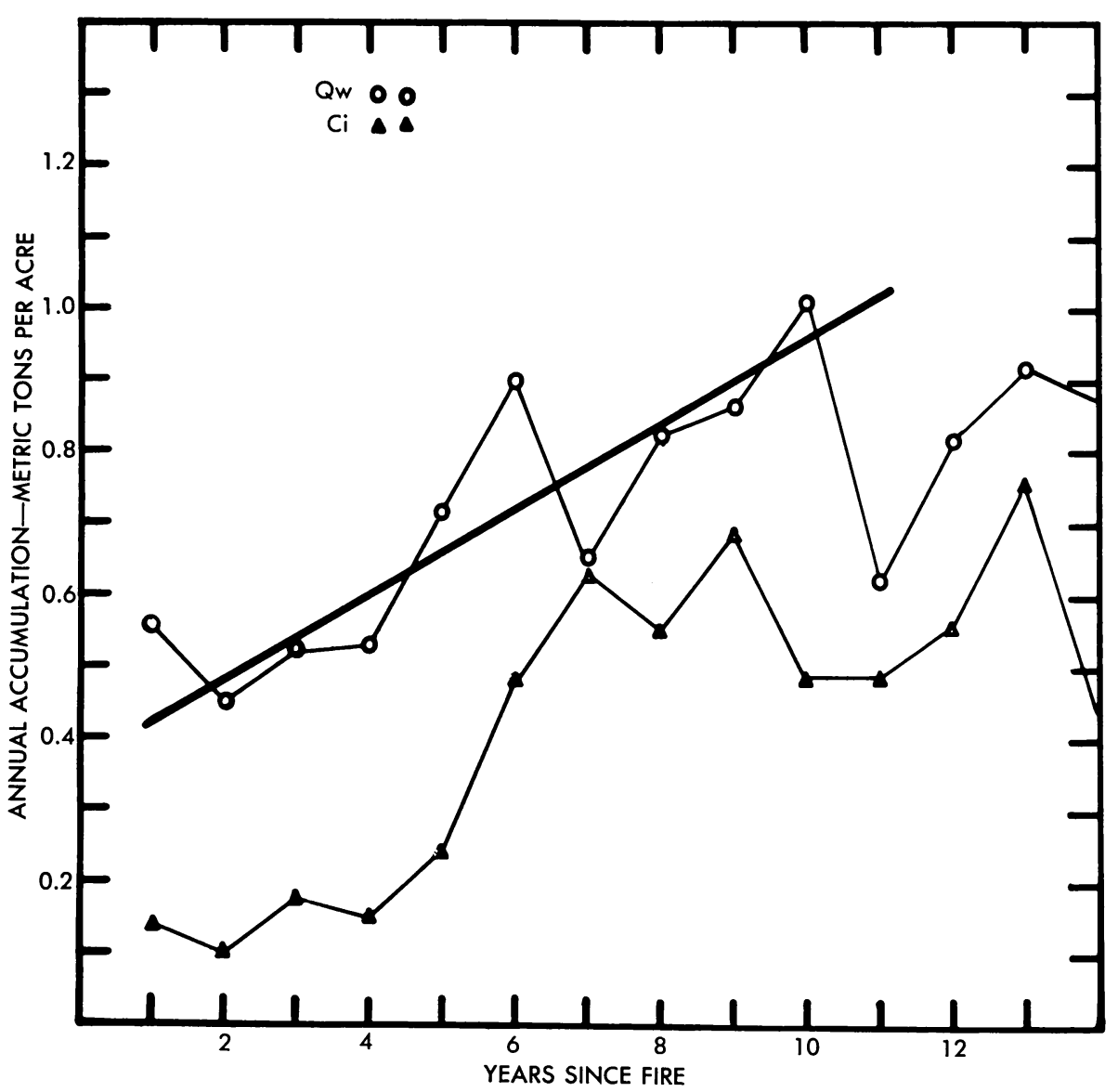

Fig. 11.-Trends of annual accumulation of litter with years since fire in the interior live oak $(\mathrm{Qw})$ and deer brush $(\mathrm{Ci})$ types of Fern Canyon.

(fig. 11). The Eastwood manzanita (Agl) increases more steeply-an average of 0.13 metric ton per acre for the first eight years-and then decreases (fig. 10). The most rapid increase was in the bigberry manzanita (Arctostaphylos glauca)-chaparral whitethorn ( $\mathrm{Cl}$ ) type for the five years from age 10 through age 14, at the rate of 0.27 metric ton per acre (fig. 10). In the same five years, the pure whitethorn $(\mathrm{Cl})$ type increased at an accelerating rate. The trend for deer brush ( $\mathrm{Ci}$ ) in figure 11 suggests the usual growth curve-a slow rise for the first four years, a rapid rise from four to nine years, and a decrease from nine to 14 years. The culmination of growth at nine years seems early by comparison with tree species, and needs confirmation. This and the other examples of decreasing trends after 
1947 may be associated with insufficient moisture for normal growth in the dry years of that period.

The annual accumulation in the first year after the fire was smaller than it was in the old chaparral before the fire. However, the trays interfered with the development of some of the annual plants so that their contribution to the annual accumulation is probably not completely represented by the amounts collected. As the brush increased with age, it came to equal or exceed that of the old growth. The number of years required to reach this equality of deposition of litter has significance as an indication of the amount of time required to recover the protective value of the chaparral after a fire. In the chaparral whitethorn ( $\mathrm{Cl})$-bigberry manzanita $(\mathrm{Ag})$ type, the annual accumulation reached an amount equal to that before the fire only after 14 years. When bigberry manzanita $(\mathrm{Ag})$ predominated, the recovery time was 13 years. In contrast, the sprouting species, Eastwood manzanita $(\mathrm{Agl})$, exceeded the prefire average in seven years, although the excess was not maintained in five of the subsequent years. Similarly, the two types of live oak that sprouted vigorously produced as much litter in six years after the fire as the 50-year stand did before the fire. The greater excesses in later years will presumably reach a maximum at the culmination of growth, which will probably be at an age younger than the 50 years of the stands before the fire.

The mean annual accumulations, averaged for the years 1935-38, are arranged in descending order by types and groups in table 13. The range from 2.0 to 0.2 metric tons per acre is quite wide, and many of the types with heavy litter are significantly different from those with light accumulations. The average of 0.74 metric ton per acre for the medium group containing most of the oak types is significantly lower than the 1.60 of the high group in which the manzanitas predominated, and significantly higher than the 0.35 of the low group with types in which chamise (Af) and chaparral whitethorn $(\mathrm{Cl})$ predominated. The average for all types is 0.81 metric ton per acre. These averages represent a condition of stability, or at least of very slow change, in the stands more than 50 years old. Comparable averages could be computed for the 14 years since the fire or for the last five years, but they would mean little because the stands are changing rapidly in size and density.

The dry weights of annual accumulations tended to increase as the crown coverage increased, but even in the same year and the same chaparral type, the relation was usually not sufficiently well-defined to be useful for purposes of estimation. Three exceptions provided indications of the forms the relation might take. In Bell Canyon in 1935, in the chamise (Af)-hoaryleaf ceanothus (Cer) type, dry weight in metric tons per acre $(W)$ increased, with crown coverage $(C)$, at a decelerating rate which could be expressed as $W=1.3 C^{\frac{1}{2}}$. In the same year, however, the types in which the ceanothus predominated showed a quite different accelerating trend as crown coverage increased up to 1.0. In Fern Canyon, the manzanita types in 1935, 1936, and 1937 had a poorly defined trend that became less steep above 0.6 coverage. On the other hand, also in 1935, the interior live oak (Qw) showed definite acceleration from 0.6 to 1.0 coverage. After the fire, however, when the stands were eight, nine, and 10 years old, the trend was linear and 
could be represented as $W=1.5 C+0.1$. Obviously, other variables obscure or modify the relation between annual accumulation and crown coverage.

For comparison with the annual accumulations, the weights of forest floor are also given in tables 11 and 13. In Bell Canyon, the floor was generally from 2.4 to 7.9 times the amount of litter. In Fern Canyon before the fire, the ratios varied from 11.4 to 23 .

With the data of annual accumulation and total weight of forest floor, it becomes possible to estimate annual loss by decomposition, the number of years until loss balances accumulation, and the weight of floor when this equilibrium is reached (table 14). In Bell Canyon, the difference between the dry weights of floor in $1933\left(F_{1}\right)$ and $1950\left(F_{2}\right)$, divided by the 17 years between samplings $(n)$, gives the annual rate of change including effects of accumulation and decomposition. The annual accumulations collected each year do not include decomposition. Therefore, by subtracting the annual change in weight of floor from the annual accumulation $(a)$, the annual loss by decomposition $(L)$ is obtained. As a formula, $L=a-\left(F_{2}-\right.$ $\left.F_{1}\right) / n$. When the annual loss is expressed as a fraction of the total floor, averaged for 1933 and 1950, figures are obtained for the fraction of floor decomposed in one year $\left(K^{1}\right)$. Jenny, Gessel, and Bingham (6) have shown that when tree species reach an age when an equilibrium between loss and accumulation is attained, the weight of floor $\left(F_{E}\right)$ can be expressed as $F_{E}=\left(a-K^{1} a\right) / K^{1}$. At any time $(T)$ in years when the weight of floor $(F)$ is known, $F_{E}=F /\left(1-e^{-K T}\right)$, where $e$ is the base of natural logarithms and $K=-\ln \left(1-K^{1}\right)$. An approximation of the years to reach equilibrium, or 95 per cent of equilibrium, is obtained by computing $T=3.0 / K$. After the weight of floor at equilibrium $\left(F_{E}\right)$ is known, the amount of floor $\left(F^{\prime}\right)$ at any number of years after a fire $(T)$, can be computed as $F=F_{E}\left(1-e^{-K T}\right)$. It is interesting to note that the same form of equation, $C_{T}=C_{\min }+C_{\max }(1-$ $e^{-K T}$ ), was used by Anderson and Trobitz (2) to estimate the cover density $(C)$ at any time $(T)$ after a fire in the same chaparral region. After most fires in the chaparral, the minimum cover density is zero, and the maximum cover density is that found some 40 years after a fire when the forest floor would have reached equilibrium $\left(F_{E}\right)$. In fact, the stable state of the forest floor is reached in most types in Bell Canyon in eight to 20 years rather than in 40 . It is possible that the floor becomes stable more rapidly than does the crown coverage, but the data on coverage and annual accumulation in foregoing sections indicate that the increases after 15 years are quite small. The values of $K$ in different types ranged from 0.04 to 0.26 , as did the $K$ values for the forest floor equation. Thus, although a usable relation between crown coverage and weight of forest floor was not found in these data, the theoretical existence of such a relation seems evident. Actually, however, it may sometimes be obscured by other factors.

In most of the types in Bell Canyon the annual loss was about equal to the annual accumulation, and was not far from 1 metric ton per acre. This would indicate that equilibrium was reached when the chaparral was about 14 years old. In confirmation, the calculated time to equilibrium was between eight and 21 years in all but two of the types. From 13 to 32 per cent of the floor decomposed annually. The computed dry weights of floor at the 
TABLE 14

ANNUAL GAINS AND LOSSES, YEARS TO EQUILIBRIUM, AND DRY

WEIGHTS OF FLOOR AT EQUILIBRIUM, BY

CHAPARRAL TYPES*

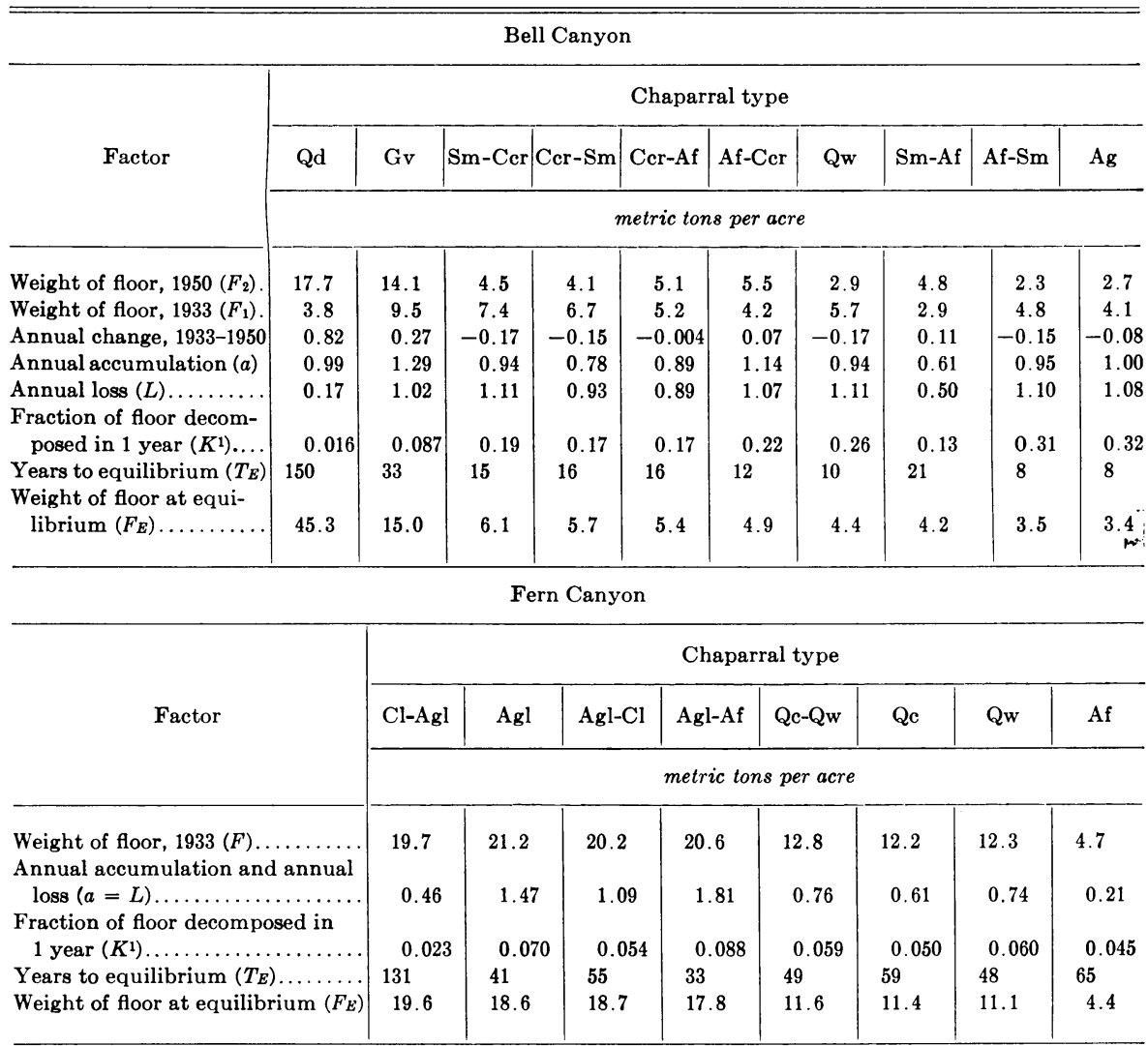

* Af, Adenostema fasciculatum, chamise

Ag, Arctostaphylos glauca, bigberry manzanita

Agl, A. glandulosa Eastw., Eastwood manzanita

Cer, Ceanothus crassifolius, hoaryleaf ceanothus

$\mathrm{Ci}, \mathrm{C}$. integerrimus, deer brush

Cl, C. leucodermis, chaparral whitethorn

Eff, Eriogonum fasciculatum var. foliolosum, California buckwheat

Gv, Garrya veatchii, silktassel

Pa, Photinia arbutifolia, Christmasberry

Qc, Quercus chrysolepis, canyon live oak

Qd, Q. dumosa, scrub oak

Qw, Q. wislizenii, interior live oak

Ro, Rhus ovata, sugarbush

Sm, Salvia mellifera, black sage

time of equilibrium were, with two exceptions, from 3 to 6 metric tons per acre, in the same range as the actual weights in 1933 and in 1950.

In Fern Canyon, the chaparral and live oak were over 50 years old when the samples of floor were collected before the fire in 1933. It is reasonable to assume that, at that age, equilibrium had been reached and, therefore, that the annual loss equalled the annual accumulation. The dry weights ranged from 0.2 metric ton per acre for chamise (Af) to 1.8 metric tons 
for Eastwood manzanita ( $\mathrm{Agl}$ )-chamise (Af). From 2 to 9 per cent of the floor decomposed each year. Equilibrium was established, with one exception, in from 33 to 55 years, thus confirming the assumption of equilibrium at 50 years. The dry weights of floor at equilibrium varied from 4.4 metric tons per acre in the chamise (Af) type to 19.6 metric tons in the chaparral whitethorn $(\mathrm{Cl})$-Eastwood manzanita $(\mathrm{Agl})$ type. These weights correspond closely to the actual weights found in 1933.

Although Fern Canyon above 4,700 feet and Bell Canyon below 3,500 feet are quite different in vegetation and site, certain general comparisons have some interest. Annual accumulations and losses were not very different, but the total amounts of floor averaged 3.7 metric tons per acre in Bell and 15.1, or four times as much, in Fern. Consequently, the fraction of floor decomposed in one year was only about one fourth as large in Fern as in Bell, and the time to equilibrium was much longer in Fern than in Bell Canyon. Similar relations to elevation were found by Jenny, Gessel, and Bingham (6) on the west slope of the Sierra Nevada, where $K^{1}$ tended to decrease, and time to equilibrium to increase, as the elevation increased. A condition of equilibrium, however, may not be necessary in order to provide the soil with sufficiently effective protection from erosion following a fire.

Several sets of erosion plots in the southern California chaparral after fires have shown accelerated erosion that continued at a decreasing rate for three years and thereafter became negligible $(1,15)$. Records of sedimentation in reservoirs, however, indicate that erosion rates after a fire do not return to normal for eight to 10 years $(4,15)$. In Bell Canyon, eight to 10 years would be long enough for the forest floor to reach equilibrium of 3.5 to 4.5 metric tons per acre in the Eastwood manzanita (Agl), chamise (Af)black sage $(\mathrm{Sm})$, and interior live oak $(\mathrm{Qw})$ types. For other types that require more than 10 years to reach equilibrium, the amount of floor that would accumulate in 10 years $(T)$ may be estimated by the use of the equation, $F=F_{E}\left(1-e^{-K T}\right)$, by substituting values for $F_{E}$ and $K$ from table 14 . For the types in which hoaryleaf ceanothus is predominant, the weight of floor at 10 years would be 4.6 or 4.8 metric tons per acre, or 85 per cent of the equilibrium values. For the black sage $(\mathrm{Sm})$-chamise (Af) type, the weight of floor would be 3.2 metric tons per acre. In general, for Bell Canyon, 3 to 5 metric tons per acre or 0.2 to 0.4 inch depth of floor is the amount that may be expected to accumulate in 10 years after a fire. During this same period of time after a fire, several factors in combination operate to cause the rate of sedimentation to return to normal. Therefore, the 0.2- to 0.4inch depth of floor should be sufficient, along with the other stabilizing factors, to contribute to the control of accelerated erosion. This range from 3 to 5 metric tons per acre corresponds closely with the weights of floor found in Fern Canyon in 1950, 11 years after the fire. Interior live oak (Qw) had 3.9 ; canyon live oak (Qc), 4.1; deer brush ( $\mathrm{Ci}), 5.1$; and Eastwood manzanita $(\mathrm{Agl}), 5.4$ metric tons per acre. In comparison, the values computed by the formula for 10 years after a fire are: for interior live oak $(\mathrm{Qw})$, 5.1; for canyon live oak (Qc), 4.6; and for Eastwood manzanita (Agl), 9.6 metric tons per acre. Apparently the formula applied to the Fern Canyon types indicates somewhat larger amounts of floor in 10 years than are actu- 
ally accumulated. If a generalization for the whole zone from 2,500 to 5,000 feet elevation is justified, it might be that 5 metric tons per acre, or $1 / 2$ inch of floor, does as much toward providing satisfactory watershed protection as can be expected from the development of forest floor in depth.

If the three years after a fire, when erosion becomes negligible on the erosion plots on slopes, are accepted as a basis, the amount of floor that accumulates in three years is, of course, much less than that accumulated in 10 years. Instead of 5 , the amount would be more nearly 2 metric tons per acre, or 0.2-inch depth. Until more evidence becomes available that so light a floor gives adequate cover of the surface, it is safer to use the 5 metric tons per acre as the criterion. Some support for the higher figure may be derived from the conclusion by Rowe (11), for Monterey pine, that floors $1 / 2$ inch deep completely control erosion. The chamise (Af) and chamiseblack sage (Sm) mixtures are the types that are least likely to develop floors of 5 metric tons per acre in 10 years.

\section{SUMMARY}

Samples of the accumulation of litter were collected annually from 1935 to 1953 , and samples of the total forest floor, in 1933 and 1950. They represented the different types of chaparral in Bell Canyon at elevations between 2,500 and 3,500 feet and in Fern Canyon between 4,500 and 5,400 feet. Both areas are in the San Dimas Experimental Forest. The samples provide the basis for the following statements as to the characteristics and relations of these materials in different types, ages, and densities of chaparral.

1. Crown coverage increased from 0.7 to 0.8 as the chaparral grew from 14 to 31 years old in Bell Canyon. In Fern Canyon, 11 years after the fire of 1938 , coverage averaged 0.8 , as it did in the 50 -year-old stands before the fire.

2. Coverage of forest floor was 0.7 at 14 years, and remained at $0.7,31$ years after the fire of 1919 in Bell Canyon. In Fern Canyon, the 50-year chaparral before the fire had 0.87 floor coverage, and only 0.7411 years after the fire. The live oaks and manzanita contribute the largest coverage of floor.

3. Crown and floor coverage, on the average, do not differ by more than 0.1 , and they tend to be equal at about 0.8 . The relation between them can be represented as $F=0.9 C^{1 / n}$, where $n$ varies between 2 and 4 .

4. Depth of forest floor in Bell Canyon increased from 0.2 to 0.4 inch as the chaparral grew from 14 to 31 years old. In Fern Canyon, the 11-year chaparral floor averaged 0.4 inch as compared with 0.6 inch in the 50-yearold stands before the fire.

5. Dry weight of forest floor in Bell Canyon after separation of mineral matter, at 14 years, averaged 5.3 metric tons per acre, and at 31 years, 5.2 tons per acre. In Fern Canyon, the 11-year stands had only 3.7 metric tons per acres as compared with 15.1 tons in the 50-year stands.

6. Dry weight increased with depth according to the equation, $W=9.7 D+$ 0.4 where $W$ is in metric tons per acre and $D$ is depth in inches.

7. Volume weights in different types of chaparral varied from 0.03 to 0.26 . 
The average for Bell Canyon was 0.12 , as compared with 0.09 for Fern Canyon.

8. Field moisture capacity, or retention storage, as per cent of dry weight, varied from 115 to 205 in different types. The average of 139 per cent for Bell Canyon is distinctly lower than the 151 per cent for Fern Canyon. Chamise (Af) and Eastwood manzanita (Agl) have low percentage field capacities.

9. Retention storage, as depth of water, averaged 0.06 inch in Bell and 0.05 inch in Fern Canyon. Scrub oak (Qd) floor retained 0.22 inch, but the whitethorn ( $\mathrm{Cl}$ ) and chamise (Af) types, less than 0.04 inch. In most of the other types, storage was between 0.03 and 0.07 inch. In any type, only the light showers or small proportions of heavier rains would be retained, subject to loss by evaporation.

10. Depth of retention storage $(d)$ can be approximated from the relation to depth of forest floor $(D)$, in Bell Canyon as $d=0.14 D+0.004$, and in Fern Canyon as $d=0.11 D+0.01$.

11. Annual accumulation of litter after the chaparral was 16 years old varied from year to year. But it did not increase with age except in two types in Bell Canyon where, for 11 years, the rates of increase were 0.07 and 0.08 metric tons per acre per year, respectively. The means of annual accumulation were 0.98 metric ton per acre in Bell and 0.81 for the 50-year stands in Fern Canyon.

12. Manzanita deposited large accumulations of litter. Black sage ( $\mathrm{Sm})$ and chamise (Af) produced small amounts of litter.

13. After the fire in Fern Canyon, the rates of increase in annual accumulation varied from 0.02 metric ton per acre, in the chaparral whitethorn (Cl)-Eastwood manzanita (Agl) type, to 0.13 ton per acre in the pure Eastwood manzanita type. For canyon live oak (Qc), the trend for the 14 years was $W=0.07 T+0.22$.

14. The sprouting species, Eastwood manzanita (Agl) and live oak, produced as much litter six or seven years after the fire as did the 50-year stands before the fire. The nonsprouting species, bigberry manzanita (Ag) and chaparral whitethorn $(\mathrm{Cl})$, were 13 or 14 years old before they deposited as much as the old stands.

15. Annual accumulation tended to increase as crown coverage increased, but the trends in different types and years were different and usually not well defined.

16. Annual loss by decomposition was between 0.5 and 1.5 metric tons per acre in most types. Losses equalled accumulations at ages of eight to 21 years in Bell Canyon where from 13 to 32 per cent of the floor decomposed annually. At the time of equilibrium, the dry weight of floor was from 3 to 6 metric tons per acre. In Fern Canyon, the losses equalled accumulations in from 33 to 55 years. From 2 to 9 per cent of the floor decomposed each year. The weight of floor at the age of equilibrium was between 11 and 20 metric tons per acre.

17. Ten years after a fire, when erosion rates have returned to normal, the weight of floor would be about 5 metric tons per acre or $1 / 2$ inch in depth. Chamise (Af) types with or without black sage (Sm) are the least desirable, 
and the types with sprouting Eastwood manzanita (Agl), pure or mixed, are the most desirable for providing that amount of forest floor in 10 years.

\section{ACKNOWLEDGMENTS}

The help of the following willing and faithful assistants in the field and in the office is gratefully acknowledged: W. B. Critchfield; W. E. Davis; M. B. Dickerman; H. A. Fowells; P. G. Haddock; W. R. Howden; E. D. Marshall; S. W. Meso; K. A. Taber ; K. F. Thielking; J. Vlamis ; C. C. Wilson; and P. J. Zinke.

It is also a pleasure to express my appreciation of the cordial coöperation of J. D. Sinclair and other members of the San Dimas Experimental Forest, who facilitated the work in many ways.

\section{LITERATURE CITED}

1. AdAms, F., P. A. Ewing, and M. R. HUbertry

1947. Hydrologic aspects of burning brush and woodland-grass ranges in California. California Div. Forestry: 1-84.

2. Anderson, H. W., and H. K. Trobitz

1949. Influence of some watershed variables on a major flood. Jour. Forestry 47: $347-56$.

3. Biswell, H. H.

1951. Plant succession in undisturbed chamise. California Div. Fish and Game, Quart. Prog. Rpt., July 1, 1951:20-23.

4. Colman, E. A.

1953. Vegetation and watershed management. 412 pp. Ronald Press Company, N.Y.

5. HoRToN, J. S.

1941. The sample plot as a method of quantitative analysis of chaparral vegetation in southern California. Ecology 22:457-68.

6. Jenny, H., S. P. GEsseL, and F. T. Bingham

1949. Comparative study of decomposition rates of organic matter in temperate and tropical regions. Soil Sci. 68:419-32.

7. KITTREDGE, J., JR.

1939. The annual accumulation and creep of litter and other surface materials in the chaparral of the San Gabriel mountains, California. Jour. Agr. Res. 58: $537-41$.

8.

1939. The forest floor of the chaparral in San Gabriel mountains, California. Jour. Agr. Res. 58:521-35.

9 .

1948. Forest influences. 394 pp. McGraw-Hill Book Co., N.Y.

10. Rowe, P. B.

1948. Influence of woodland chaparral on water and soil in central California. U. S. Forest Service and California Div. of Forestry. $70 \mathrm{pp}$.

11.

1955. Effects of the forest floor in disposition of rainfall in pine stands. Jour. Forestry (in press).

12. SHAw, C. R.

1927. The normal moisture capacity of soils. Soil Sci. 23:303-17.

13. SinClatir, J. D., and E. L. HAMilton

1953. A guide to the San Dimas Experimental Forest. U. S. Forest Service, California Forest and Range Exp. Sta., Mise. Paper No. 11, 17 pp. 
14. Tarrant, R. F., L. A. IsaAc, and R. F. Chandler

1951. Observations on litter fall and foliage nutrient content of some Pacific Northwest tree species. Jour. Forestry 49:914-15.

15. U. S. FOREST SERVICE

1951. Some aspects of watershed management in southern California. California Forest and Range Exp. Sta., Misc. Paper No. 1, 29 pp.

16.

1951. Annual report. Rocky Mountain Forest and Range Exp. Sta., 1951:29-31.

17. Wilm, H. G., A. Z. Neison, and H. C. StoreY

1939. An analysis of precipitation measurements on mountain watersheds. Monthly Weather Rev. 67:163-72. 
The journal Hilgardia is published at irregular intervals, in volumes of about 600 pages. The number of issues per volume varies.

Subscriptions are not sold. The periodical is sent as published only to libraries, or to institutions in foreign countries having publications to offer in exchange.

You may obtain a single copy of any issue free, as long as the supply lasts; please request by volume and issue number from:

\section{Agricultural Publications \\ Room 22, Giannini Hall \\ Berkeley 4, California}

The limit to nonresidents of California is 10 separate issues on a single order. A list of the issues still available will be sent on request. 